\title{
Social impact disclosure and symbolic power: Evidence from UK Fair Trade Organizations
}

\author{
Homaira Semeen \\ School of Accountancy \\ QUT, Australia \\ Email: homaira.semeen@connect.qut.edu.au \\ Muhammad Azizul Islam ${ }^{1}$ \\ Business School \\ University of Aberdeen, UK. \\ Email: azizul.islam@abdn.ac.uk
}

\begin{abstract}
This article unravels how fair trade organizations use social impact disclosures as forms of symbolic power amid stakeholder concerns that prevail in the fair trade field. Mobilizing Bourdieu's notion of symbolic power and through narrative analysis of social impact disclosures and the associated rhetoric of major UK fair trade organizations, as well as their stakeholders' rhetoric and persuasive arguments in the public domain during the period from 2006 to 2013, we show that these organizations position themselves as dominant actors in responding to stakeholders' concerns over social inequality. We provide important insights into how social impact disclosures, silence and rhetorical strategies are used as a mechanism of symbolic power through which fair trade organizations maintain dominance over their stakeholders in the fair trade field.
\end{abstract}

Keywords: Fair trade, legitimation, social inequality, Bourdieu, symbolic power, social impact disclosures, stakeholders, silence in reporting, rhetoric.

\footnotetext{
${ }^{1}$ Corresponding author. Contact details: Chair in Accountancy and Director of Postgraduate Research Programme (Accounting and Finance), University of Aberdeen Business School, Edward Wright Building, Room: S4, Dunbar Street, King's Collage. AB24 3QY, UK. Email: azizul.islam@abdn.ac.uk. P: +441224272710; M:+447404531133
} 


\section{Introduction}

A plethora of studies have investigated different aspects of organizational social accounting and disclosures and found that organizations use these practices to maintain legitimacy (e.g. Archel, Husillos, Larrinaga, \& Spence, 2009; Campbell, 2003; Cho, Michelon, Patten, \& Roberts, 2015; Brown \& Deegan, 1998; Deegan, 2002; Deegan \& Blomquist, 2006; Islam \& Deegan, 2010; Islam \& Deegan, 2008; Lanis \& Richardson, 2013; O’Donovan, 2002; Patten, 1991, 2019; Qian, Burritt, \& Monroe, 2011). Hand in hand with these studies, research into critical domain has increasingly recognized that organizational legitimacy asserted via social accounting and disclosures may maintain unequal power relations (e.g. Arrington \& Puxty, 1991; Gallhofer \& Haslam, 1997; Gray, 2010; Islam, Deegan, \& Gray, 2018; Milne, 2002; Puxty, 1986; Tinker, Lehman, \& Neimark, 1991; She \& Michelon, 2019; Sikka, 2011; Young, 2003; Martinez and Cooper, 2017; Neu, Cooper, \& Everett, 2001). A few studies (see for example, Puxty, 1986, 1991) are more strongly critical by highlighting that organizations' legitimation processes via social accounting are problematic and may even perpetuate an existing inequitable social and political system. Despite the growing criticisms of social accounting and disclosures, research that investigates the problems of organizational social accounting and disclosure as forms of symbolic power is lacking. In fact, we know little (but see Martinez and Cooper, 2017) about how organizations with 'social justice' agendas operate, how contestation of their accountability practices is manifested, and how they produce social impact disclosures and maintain power relations in the social field. To address these research gaps, by focusing on social impact disclosure practices of fair trade organizations in the UK, we aim to explore the use of rhetoric and silence as mechanisms of symbolic power through which fair trade organizations dominate stakeholder voices and maintain unequal relations.

Fair trade is heralded as a successful ethical alliance that aims to combat socially unjust trading practices through maintaining distinctive social justice principles within a system of certification and a designated trade chain. Despite being a fertile research area, fair trade has received limited attention in the social accounting literature (Bebbington \& Larrinaga, 2014; Gray, 2002; O'Dwyer \& Unerman, 2016). To date, fair trade organizations have been examined with the aim of developing a conceptual framework for social accounts (Gray, Dey, Owen, Evans, \& Zadek, 1997), and to unravel the intra-organizational struggles associated with the implementation of social bookkeeping (Dey, 2007). In particular, the conceptual framework discussed by Gray et al. (1997) sees social impact disclosures by a fair trade organization as a democratic mechanism that consists of an existing set of accounts socially reconstructed through stakeholder voices (p. 348) and represents stakeholders, who are defined as "all those groups or parties who are influenced by and/or who influence the organization (or accounting entity)" (p. 333). Moving beyond a normative analysis of fair trade accountability practices (Gray et al., 1997), our study fills a gap in the current social accounting and sustainability literature by shedding light on the use (or practice) of social impact disclosures and related persuasive rhetoric by fair trade organizations in their inter-organizational struggles and dominance. In this study, we specifically examine the social impact disclosure practices and rhetoric of two distinct types of UK fair trade organization (full fair trade organizations and partly fair trade organizations, mainstream retailers with fair trade product lines) ${ }^{2}$ over eight

\footnotetext{
${ }^{2}$ How we categorized them is described in section 2 of this paper.
} 
reporting years (2006-2013). In addition, we analyze the disclosures and related rhetoric of their industry association, Fairtrade International (FLO), ${ }^{3}$ in conjunction with the underlying critical and persuasive rhetoric of their stakeholder groups, to capture the unequal relations and power struggles of fair trade organizations.

Our focus is on UK-based fair trade organizations as these represent the largest and oldest fair trade market in the world. Indeed, a number of pioneering fair trade organizations have been operating out of the UK for decades (Fairtrade Foundation, 2019). An analysis of the social impact disclosures of UK fair trade organizations has the potential to provide important insights into the power dynamics and associated struggles for dominance of the fair trade field. To address our research aim, we conducted narrative and contextual analysis of a wide range of social impact disclosure media used by fair trade organizations, including annual reports, social audit reports, sustainability reports, information on their official websites, and social media posts by the organizations over the period from 2006 to 2013. Additionally, we analyzed academic literature, media articles, reports by non-governmental organizations (NGO), and social media posts by stakeholder groups during the same period.

This study draws on critical accounting literature (Everett, 2002; Neu, 2006; Cooper \& Joyce, 2013; Gracia \& Oats, 2012; Cooper, Coulson, \& Taylor, 2011; Ramirez, Stringfellow, \& Maclean, 2015; Young, 2003; Brennan \& Markl-Davies, 2014; Killian \& O'Regan, 2016) and embraces Bourdieu's notion of symbolic power (Everett, 2002; Bourdieu, 1989) to identify problems in the use of social impact disclosures and legitimation strategy by fair trade organizations. Bourdieu's framework provides a theoretical spectrum for a relational analysis which facilitates to unravel that fair trade organizations use social impact disclosures and related rhetorical strategies to perpetuate domination and disregard stakeholder concerns at existing social inequalities. In other words, mobilizing Bourdieu's notion of symbolic power, our analysis of social impact disclosure practices and related rhetorical strategies by fair trade organizations offers important insight into fair trade hegemony amid the tensions, contradictions, and challenges that emanate from stakeholders in the field.

The paper proceeds by describing the background of fair trade and the research gap in the accounting literature. Next, it presents a description of how the theoretical framework accords with Bourdieu's idea of symbolic power. In the following sections, details of the research method, the results of the study and concluding remarks are provided.

\section{A brief background to fair trade}

Emerging from a political movement to fight against the poverty and inequality caused by unjust trading systems, fair trade is claimed to be one of the most prominent international ethical business alliances of recent times (Wheeler, 2012). Over the last two decades, the fair trade movement has attracted consumers' attention because of its stated, visionary goals and

\footnotetext{
${ }^{3}$ This study specifically focuses on UK fair trade organizations associated with FLO. FLO use the term 'Fairtrade' whereas some stakeholders use 'fair trade'. We have no view on the differences (if any) and use the latter term in this study to refer to both 'Fairtrade' and 'fair trade' systems operating within FLO's licensing scheme in the UK.
} 
its ambitions to challenge structural injustices in conventional trading systems (Raynolds \& Murray, 2007). This movement has generated a global market of more than 3,000 products, with over $£ 7.8$ billion in sales per year (Fairtrade International, 2018-19). ${ }^{4}$

Fair trade aims to connect disadvantaged and underprivileged farmers and workers, empower them to combat poverty and secure sustainable livelihoods, and promote conditions that encourage social justice (Fairtrade International, 2015-16; WFTO \& FLO, 2009; Wheeler, 2012). For farmers and workers, fair trade standards usually cover protection of workers' rights and of the environment, and terms for trading fairly/ethically with trade organizations/companies. These standards cover the payment of the Fairtrade Premium to farmers,${ }^{5}$ which they can invest in projects of the community's choice.

Fair trade global networks are largely operated by two major regulatory associations: ${ }^{6}$ FLO and the World Fair Trade Organization (WFTO). FLO and WFTO maintain a Charter of Fair Trade Principles jointly formulated in 2009. This Charter distinguishes fair trade from conventional trading systems by defining fair trade as:

... a trading partnership, based on dialogue, transparency and respect, which seeks greater equity in international trade. It contributes to sustainable development by offering better trading conditions to, and securing the rights of, marginalized producers and workers - especially in the South. Fair trade organizations (backed by consumers) are engaged actively in supporting producers, awareness raising and in campaigning for changes in the rules and practice of conventional international trade. (WFTO \& FLO, 2009, p. 6)

The Charter sets out a number of principles of fair trade (WFTO \& FLO, 2009), with the primary objective of establishing social equality:

- Market access for marginalized producers

- Sustainable and equitable trading relationships with producers/farmers

- Capacity building of producer organizations and empowerment of the producers

- Consumer awareness raising and advocacy

- Recognizing Fair Trade as a "social contract" between producers, buyers and consumers

- Labor and human rights (following ILO Convention)

- Improvement of the environmental impact.

A plethora of studies in different disciplines has investigated the economic model behind fair trade (Bowes, 2011; Nicholls \& Opal, 2005; Raynolds \& Murray, 2007; Sylla \& Leye, 2014), the governance structure of fair trade regulatory bodies (Gandenberger, Garrelts, \& Wehlau, 2011; Ullrich, 2011), and the impact of fair trade standards at the level of the producer (Blowfield \& Dolan, 2010; Jaffee, 2010; Jaffee \& Howard, 2010; Moore, 2004; Raynolds, 2012; Shorette, 2010-11; Valkila, 2009). Despite such diverse research activities, the accountability, transparency, hegemonic and legitimacy-related role of fair trade organizations,

\footnotetext{
${ }^{4} € 9.8$ billion in sales as reported in the Annual report of Fairtrade International 2018-19. The currency amount has been converted to sterling using the average exchange rate $€ 1=£ 0.88$ in 2018 .

${ }^{5}$ Typically, there is a Fairtrade price, plus a Fairtrade premium which goes into a communal fund for farmers and workers to improve their economic, social, and environmental conditions (www.fairtrade.org.uk/What-isFairtrade/What-Fairtrade-does/Fairtrade-Premium).

${ }^{6}$ Except in the USA, where a different regulatory body, Fair Trade USA, maintains the fair trade network.
} 
which serve as the essential link between consumers and producers, remain understudied. While some researchers (Huybrechts \& Nicholls, 2013; Nicholls, 2010) have focused on the struggles for legitimacy that fair trade organizations face when incorporating fair trade policies into business practices, they did not consider disclosure practices nor how fair trade organizations interact in the public domain through disclosures.

Previous studies have highlighted that the dual aims of ensuring social equality and securing profitability and product quality often contradict each other (Bennett, 2016; Gandenberger et al., 2011), though their social equality business objectives aim to garner for fair trade organizations a greater legitimacy than other trading organizations need (Nicholls, 2009). While fair trade aims for democratic participation by producers in decision-making, past research has shown that such attempts are challenging and often result in unresolved conflicts within the producer communities, limiting their scope for expansion (Loconto, 2015; Renard \& Loconto, 2013). In this regard, increasing participation by corporations or mainstream businesses exacerbates challenges to fair trade practices, since they, as partly fair trade organizations, seek weaker fair trade standards that facilitate capital accumulation and reduce challenges to their existing practices (Huybrechts \& Nicholls, 2013; Jaffee \& Howard, 2010). While previous research has highlighted tensions, contradictions, and challenges in the field of fair trade, it has not focused on the rhetorical response of fair trade alliance members via social impact reporting practices in the public domain. In particular, the social impacts of fair trade organizations are not vividly explored in the accounting literature. Even though studies in other fields (Huybrechts \& Nicholls, 2013; Nicholls, 2010) focus on fair trade organizations' struggles for legitimacy and to implement fair trade policies, there is a lack of research into how fair trade organizations use particular disclosure practices amid contradictions and challenges that emanate from stakeholders in the field. Our study focuses specifically on the social impact disclosure practices of the UK fair trade organizations licensed by and associated with FLO. Fair trade organizations in the UK have played a significant role in outlining and expanding the concept of fair trade across the globe (Hutchens, 2009; Nicholls \& Opal, 2005). They represent the largest market in the world for fair trade products, with a turnover of over $£ 1$ billion annually (WFTO \& FLO, 2018). FLO's labelling scheme has provided the fair trade system with the scope to achieve commercial breakthroughs by allowing corporations that might not embrace fair trade principles for all of their products to enter the fair trade network (Hutchens, 2009). Given this, Hutchens (2009) categorized fair trade organizations as (1) a first group, which sells only fair trade-branded products to mainstream consumers - most of them are either not-for-profit or social enterprises, and (2) a second group that sells a few fair trade products along with their regular product lines - most of them are mainstream corporate retailers. For the purpose of our study, we have adopted her classification of the first group as full fair trade organizations and the second group as partly fair trade organizations.

Past accounting research indicates that there remains a missing link between corporate social accountability (including social reporting and auditing) and stakeholder voices (Cooper \& Owen, 2007; Islam et al., 2018). Current social accountability mechanisms (including social auditing: see Islam et al., 2018)) often involve a system in which one or more parties dominate, which does not always consider stakeholders' voices (Archel et al., 2011). In particular, Dey's 
(2007) study of the incorporation of an accounting system into a major fair trade intermediary, Traidcraft plc, offers insights into how the intermediary struggled to maintain ethical trading relationships as internal political and social pressures arose. Given that, we argue that it is also important to investigate and identify the problems in how social impact disclosure practices by fair trade organizations play (or have struggled to play) a role in maintaining power relations among external and wider stakeholder groups. Fair trade organizations regularly report on relationships with a range of external stakeholders such as third-party certification bodies, news media, local NGOs, and local governments. ${ }^{7}$ Accordingly, it is also important to examine whether and how external stakeholders become engaged (Archel et al., 2011) in producing persuasive rhetoric for and against the social impact of fair trade business operations.

\section{Theoretical framework: Bourdieu's notion of symbolic power}

In line with O'Dwyer and Unerman's (2016) call for further research, we argue that an investigation of social impact disclosure by fair trade organizations requires relatively critical theories rather than system-oriented theories. ${ }^{8}$ In particular, where the studies driven by system-oriented theories highlighted organizational strategies to legitimize through public disclosures backed by institutional and structural power, these do not expand our understanding of the problematic aspects of organizational legitimacy. Accordingly, research based on critical theories (Everett, 2002; Neu, 2006; Cooper, Coulson, \& Taylor, 2011; Ramirez, Stringfellow, \& Maclean, 2015; Chwastiak \& Young, 2003; Young, 2003; Killian \& O'Regan, 2016) is important in examining organizations' problems with legitimacy and the role of particular forms of disclosure in maintaining their unequal power relations with stakeholder groups. In view of this, we embrace Bourdieu's notion of symbolic power to support our investigation into social impact disclosure practices by fair trade organizations.

From a broader range of critical theories, Bourdieu's theoretical arguments help us to analyze the language used in social impact disclosures in relation to the varying social positions of fair trade organizations within the continuum corporation-social enterprise-non-profit NGO. Such relational analysis enabled us to unravel how such disclosures appear to dominate societal dispositions of fair trade. Bourdieu defines symbolic power as legitimate power that accounts for cultural or social domination occurring within the everyday social habitus. It is an act of cognition and misrecognition that exists (Ramirez, Stringfellow, \& Maclean, 2015) beyond or beneath the control of consciousness and will (Eagleton \& Bourdieu, 1992; Everett, 2002). Symbolic power primarily requires the dominator and the dominated to accept their positions in the exchange of social value or capital that occurs between them. Symbolic power is not an

\footnotetext{
${ }^{7}$ Our analysis of annual reports of fair trade regulatory NGOs, FLO and WFTO, as well as our review of the existing fair trade literature (e.g. Gandenberger et al., 2011; Ullrich, 2011) reveals that fair trade organizations maintain regular communication with governments and NGOs in the countries in which they operate to improve the social and environmental impact of their business operations.

${ }^{8} \mathrm{~A}$ plethora of studies have adopted system-oriented theories, such as legitimacy theory (Bebbington, Larrinaga, \& Moneva, 2008; Belal \& Owen, 2015; Islam and Deegan, 2010), neo-institutional theory (Qian, Burritt, \& Monroe, 2011), stakeholder theory (Wong \& Millington, 2014), and the theory of impression management (Conway, O'Keefe, \& Hrasky, 2015). While previous research is acknowledged here, there has been some scholarly criticism (Mobus, 2005; Owen, 2008) of the extensive use of system-oriented theories (including legitimacy theory) to explain motivations for social reporting practices.
} 
isolated concept but rather a rationale that relates to the different forms of capital Bourdieu explains: economic, cultural, social, and symbolic (Bourdieu, 1986). While different forms of capital can be transformed into symbolic power, Bourdieu argues that symbolic capital constitutes the ultimate basis of symbolic power, as it imposes a legitimate vision of the world and the way in which social fields are organized in a particular order (Everett, 2002). A dominator may use words, language, text, or any other rhetorical mechanism (such as persuasive action and silence) to exercise symbolic power. As Bourdieu explains:

Symbolic power is the power of making things with words... [it] aims at imposing the vision of legitimate division... in this sense, symbolic power is a power of "world making"... [that] consists of ... "separating and reuniting, often in the same operation", in carrying out a decomposition, an analysis, and a composition, a synthesis often by the use of labels... (Bourdieu, 1989 pp 22-3)

Language is a mechanism for forming symbolic capital and thus symbolic power through which a dominator pursues their interests (Bourdieu, 1991; Bourdieu, 1989). When individuals use language in particular ways, they deploy the linguistic elements or resources at their command (words, texts, images, evaluations, or maxims), and adapt these (e.g. words) to the demands of the social field or market that is their audience. Language actively assists in constructing the conditions in which we live and at the same time it also acts to limit those conditions since it is embedded in or embeds dominant text, words, or images (Chwastiak \& Young, 2003). Dominant text, for example, can be a mechanism through "which the injustices arising from an unequal distribution of wealth and power are rationalized and justified" (Chwastiak \& Young, 2003, p. 534; see also Eagleton \& Bourdieu, 1992). Bourdieu contends that language serves as both the platform and the weapon for wielding symbolic power in a restricted field (Webb, Schirato, \& Danaher, 2002). Language extends structures and media to create meaning and understanding and therefore possesses symbolic power to determine a legitimate vision of the world (Webb et al., 2002). Considering social impact disclosure and the related rhetoric as an instrument of symbolic power, our study investigate how major organizations in the field of fair trade maintain power relations and legitimacy.

As language is a mechanism of symbolic power, we rely on three features of organizational communication through which language or texts can be examined or evaluated: social impact disclosures, disclosure-related rhetoric or persuasive arguments, and silence in reporting. Brief descriptions of these three features follow.

\subsection{Social impact disclosures and symbolic power}

A growing body of disclosure literature suggests that organizations use social disclosures as a response to public pressures or pressures from wider stakeholder groups (Archel et al., 2009; Patten, 1991). In other words, previous research has found that disclosures are used as a tool for maintaining organizational legitimacy and an unequal distribution of power among the wider community. In this study we frame social impact disclosures not only as a response to stakeholder pressures but also as a mechanism of symbolic power (in line with Bourdieu, 1991, 1989) through which fair trade organizations pursue (or struggle to pursue) their dominance and interests amid stakeholder concerns. While the symbolic power of social accounting is well recognized in accounting literature that draws on Bourdieu (Cooper et al., 2011; Killian \& 
O'Regan, 2016; Rahaman et al., 2007), that work sheds limited light on how social impact disclosures by a group of organizations concurrently contribute to legitimizing a vision of practices and maintain dominance - or in Bourdieu's terms, "world making" - with words or text. We extend the conceptualization of social accounting as symbolic power (Killian \& O'Regan, 2016), and consider the contradictions and challenges in maintaining power relations with stakeholders at the field level.

\subsection{Disclosure-related rhetoric and persuasive arguments and symbolic power}

According to Bourdieu, symbolic power is wielded when words or text are rhetorical or persuasive and are "... adequate to things, that description makes things" (Bourdieu, 1989, p. 23). Rhetoric or persuasive language used in social impact disclosures is an important mechanism of symbolic power through which both a dominator and a dominated pursue their positions and interests. While the dominator uses a persuasive text to maintain the dominance position, the dominated use text to evaluate or devalue the dominator's interest. The rhetorical exchanges between dominator and dominated may force the dominator to struggle to maintain its power relation and legitimacy. In other words, the persuasive arguments a dominator deploys to maintain its symbolic power might not remain unquestioned, and symbolic violence may follow. Where actions are rooted in rhetoric that "lead[s] to unequal distribution of capital, there is symbolic violence: the symbolic domination of the dominant, a domination that implies the complicity of the dominated" (Everett, 2002, p. 69). Our study extends this understanding by demonstrating how social impact-related rhetoric is used by dominant fair trade organizations with different social positions, and how these organizations struggle to maintain their power relations amid contradictions and challenges posed by stakeholder groups (news media, academics, members of the broader community).

Past accounting literature highlights that rhetoric in corporate reporting can be used to convince or persuade particular stakeholder groups (see for example, Davison, 2008; Laine, 2009; Merkl-Davies, Brennan, \& McLeay, 2011). However, little is known about how organizations use rhetoric in corporate reporting as symbolic power, to reinforce hegemony (Bourdieu, 1991). Brennan and Markl-Davies (2014) examined the use of rhetoric by a powerful stakeholder (Greenpeace) as a means of persuading fashion firms to review their values and improve their social and environmental choices, and found that it was impossible for fashion firms to ignore Greenpeace's demand to eliminate hazardous chemicals from their supply chains. Laine (2009) examined a range of rhetorical features of disclosures by a leading Finnish chemical company over a long period (34 years), including reactive, efficiency-driven, defensive, positive, and value-driven persuasive arguments, and found that the rhetoric was used and adjusted over time as a response to varying institutional pressures in order to maintain a dominant position in society. Our study extends research of this kind by examining rhetorical texts issued both by fair trade organizations and by their stakeholders, to understand hegemony and the contradictions that arise in maintaining fair trade organizations' social positions.

\subsection{Silence in reporting and symbolic power}

Silence, as a language or a communication tool, can also be seen as an effective mechanism of symbolic power through which dominators seek to advance their hegemonic interest. Without necessarily referring to Bourdieu's (1991) notion of symbolic power, Chwastiak and Young 
(2003) argued that silences are embedded in corporate reports because financial or economic capital (more generally, the values of capitalism) is blatantly celebrated in such reports. They found that corporate reports rely upon the silencing of injustices (such as negative social and environmental impacts of their activities) "in order to make profit appear to be an unproblematic measure of success" (Chwastiak \& Young, 2003, p. 548). In another study, by focusing on the (US) Financial Accounting Standards Board's (FASB) standard-setting process, Young (2003) argued that criticism of exposure drafts raised by respondents and possible alternative suggestions presented by them to FASB were greeted with silence. She also argued that FASB employed rhetorical strategies through shaping the text of standards to express their point of view and thereby persuade readers to accept their perspective. In this paper, we argue that any stakeholder criticisms of the social impacts of fair trade are silenced by fair trade organizations in order to maintain their hegemonic interests in the public domain.

The three features of organizational communication that we have focused on here are not intended to be an exhaustive list, but in some senses they are illustrative. All of these features contribute to portraying hegemony, social inequalities, and struggles for organizational legitimacy. In light of these features, we analyze the nature of social impact disclosure practices in the fair trade field to unravel the symbolic power of those practices to dominate stakeholders' voices. While Bourdieu's framework sheds light on the ways in which linguistic usage varies with considerations such as class and gender, accounting research is employing it to illuminate other usages. It also opens up a motivation for research that investigates the ways in which language is used in the domain of fair trade business: among other things, the arena in which texts are emblems of conduct and symbolic power is at stake.

\section{Research method}

This study primarily relies on narrative or textual analysis of documents to examine the social impact disclosures and associated rhetoric of UK fair trade organizations, and the use of rhetoric and persuasive arguments by stakeholders in relation to their (fair trade organizations') social impact performance during the period from 2006 to 2013. Within the accounting literature, narrative analysis is used to gain an in-depth and holistic understanding of particular disclosures as well as the use of rhetoric and persuasive arguments with respect to motivation for particular disclosures (Beattie, 2014; Neu, Ocampo Gomez, Graham, \& Heincke, 2006). Our narrative analysis focuses on three features of organizational communication through which language or text can be examined or evaluated: social impact disclosures by fair trade organizations, disclosure-related rhetoric and persuasive arguments by both fair trade organizations and their stakeholders, and the silences in reporting produced by fair trade organizations. Given that the nature of the accounting narratives and disclosure practices of fair trade regulatory organizations is not widely understood, narrative analysis of fair trade disclosure media is considered an appropriate method to unravel the symbolic power wielded by, and the associated hegemonic interests of, fair trade organizations. The following sections describe how we selected the organizations examined, and the data collection and analysis processes. 


\subsection{Selection and sample of fair trade organizations}

Our study primarily focuses on fair trade organizations in the UK, regulated and coordinated by a voluntary regulatory body, FLO. We identified the fair trade organizations that have high public visibility. From the website disclosures of FLO's regional office, ${ }^{9}$ Fairtrade Foundation, UK and FLO's certification body, FLOCERT, we found 93 fair trade organizations: 44 full fair trade organizations and 49 partly fair trade organizations. We found that $88 \%$ of these fair trade organizations have websites, but only $18 \%$ ( 8 full fair trade and 9 partly fair trade organizations) produced annual reports or stand-alone social responsibility reports with detailed disclosures.

To understand how the symbolic power of fair trade organizations is discussed through social impact disclosures and associated rhetoric, we chose ten fair trade organizations (five full fair trade organizations - those that trade only in fair trade products, and five partly fair trade organizations or mainstream retailers - those that offer a fair trade product line alongside their conventional product lines) that appeared frequently in a variety of reporting media and regularly publish reports on fair trade practices. ${ }^{10}$ Our selection unraveled similarities as well as differences in social impact disclosures and the use of impact-related rhetoric within the fair trade field. Table 1 lists the names and gives brief descriptions of the organizations under study.

\footnotetext{
${ }^{9}$ Data for this study was primarily collected within the period 2014-16. Hence, data for 2006-13 represents online archival material collected between 2014 and 2016.

${ }^{10}$ Our study aims at investigating representations of the social impact of fair trade through accounts and disclosures in the public domain. This allows us to illustrate the struggles to construct a legitimate vision of fair trade practice in this field. Accordingly, we purposefully chose fair trade organizations in the UK that frequently interact with their stakeholders in the public domain through a range of reporting. In other words, they are significant in terms of their presence in reporting media.
} 
Table 1: List of selected Fair Trade Organizations, year of joining the alliance and significant contribution to the field of fair trade ( $\mathrm{n}=10)$

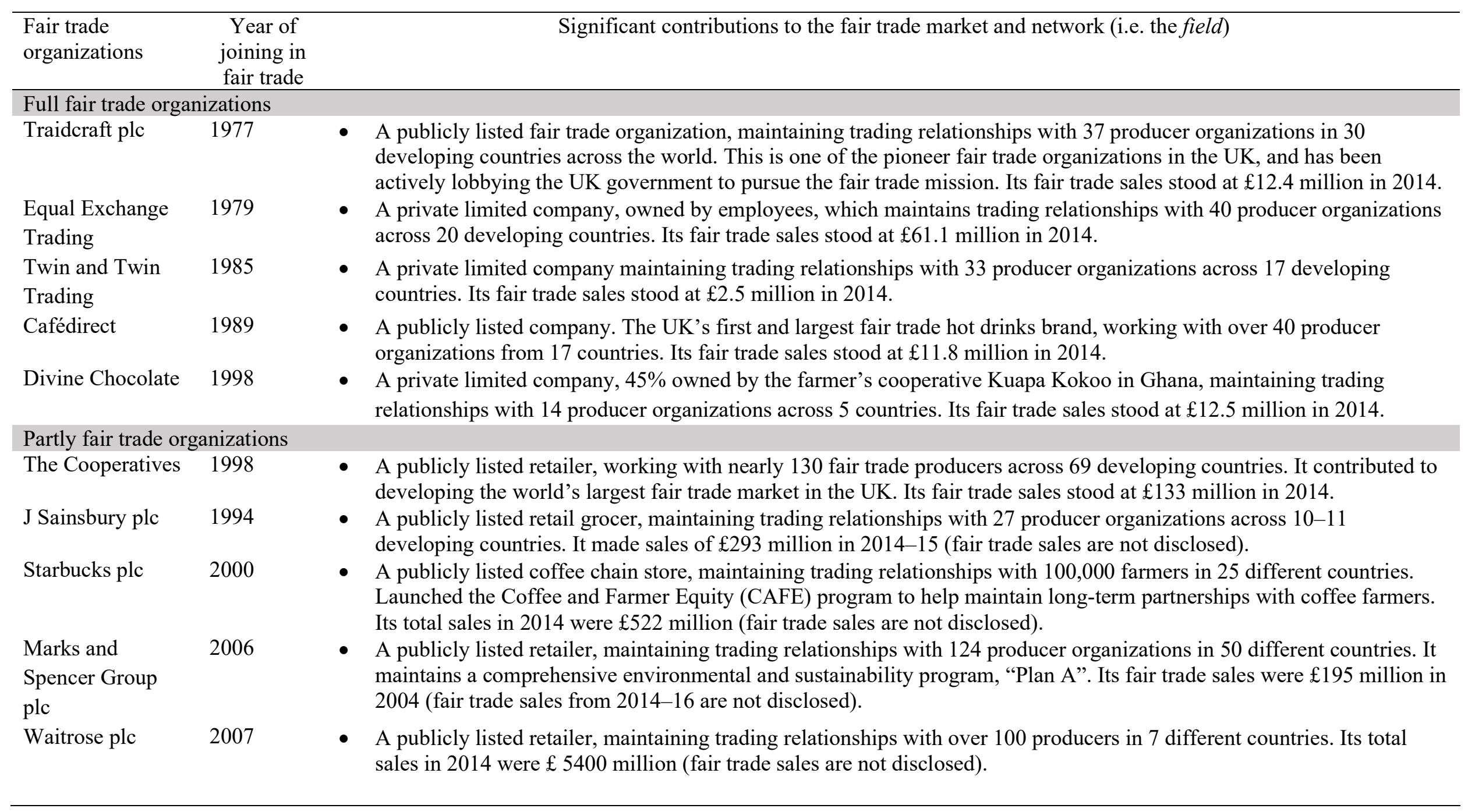




\subsection{Data collection}

To support our narrative and textual analysis, we collected three categories of documents. The first category consists of 93 reports, including regular reports such as annual reports/reviews, standalone social responsibility reports, and other non-regular reports (e.g. policy reports, briefings, and newsletters), that were published by the selected full and partly fair trade organizations and by the FLO between 2006 and 2013. These reports allowed us to systematically analyze how social disclosures were made, how rhetoric was used, and how these changed over time.

The second category of documents consists of 139 independent research articles, books, and research reports published between 2005 and 2012. These documents were used to analyze stakeholders' uses of rhetoric and persuasive arguments (for instance efficiency-related, reactive, defensive, positive/approving/appreciative, negative/depreciative/expressing concern, silences) related to fair trade practices. We primarily relied on the archive of the Fair Trade Institute (FTI), the most comprehensive online collection of fair trade publications, as well as Google Scholar.

The third category of documents consists of 236 news articles, 39 NGO reports and social media posts, and online feedback (i.e. 935 Facebook posts and comments in relation to social impact $)^{11}$ published during the period 2005-12. These were analyzed to understand how a group of stakeholders (NGOs, journalists, general consumers who use social media) used rhetoric, persuasive arguments, and expressions of concerns against fair trade organizations. News articles on fair trade issues were collected from the Dow Jones' Factiva database. Previous accounting research used media analysis to explain different accounting and disclosure phenomena (Andon \& Free, 2012; Islam \& Deegan, 2010). News articles were collected in ten rounds by searching for the organization's name, one at a time, and the subject "fair trade". Duplicate news articles were removed so as not to distort the data set. We collected 39 NGO reports from the websites of Oxfam, Comic Relief, and the International Labor Rights Forum (ILRF), all active in the fair trade field between 2005 and 2012.

Finally, the 935 Facebook posts and comments were collected using NVivo. ${ }^{12}$ Emotions and persuasive arguments that people express on Facebook influence organizational responses in the public domain (Scott \& Orlikowski, 2012; Toubiana \& Zietsma, 2017). We specifically sought comments and 'likes' that reflect particular rhetorical arguments (including approval/endorsement and criticism), as well as fair trade organizations' responses to these arguments. 'Likes' are indications of appreciation for a particular comment or post by others (Toubiana \& Zietsma, 2017). We analyzed the patterns of stakeholders' appreciations and concerns, and organizational responses.

\footnotetext{
${ }^{11}$ We found 3,995 posts in total made on fair trade organizations' Facebook pages between 2005 and 2012. Out of these, 935 posts are related to the social impact of fair trade.

${ }^{12}$ Using NVivo's NCapture function, the total data set was extracted from Facebook into NVivo then exported to an Excel file for analysis.
} 
Together, this collection of a wide range of reports, disclosures, and other documents facilitated a broad understanding of the fair trade field, the capital in possession of the actors in the field, and the symbolic power of the dominant fair trade organizations amid stakeholder concerns.

\subsection{Data analysis}

While our approach to narrative and textual analysis of documents is consistent with previous research (for example Andon \& Free, 2012; Everett, Neu, \& Rahaman, 2007; Uddin, Siddiqui, \& Islam, 2016), we made adaptations to address our specific research question. A detailed description of the process is given below.

\subsubsection{Preliminary understanding of the data}

Analysis commenced by reading the whole range of reports collected, including websites and relevant articles that documented stakeholders' perspectives. This helped us to understand and code statements both by organizations and by the other stakeholders considered.

\subsubsection{Coding}

After gaining a preliminary understanding of the data, initial codes were produced from it in light of the theoretical framework adopted. An holistic coding system (Miles, Huberman, \& Saldaña, 2014) was used to capture a comprehensive understanding of overall content. The initial coding generated 4,909 statements under three general categories/themes: economic impact, social networking impact, and sustainability impact. NVivo software was used to analyze reports and stakeholder narratives.

\subsubsection{Thematic analysis of social impact disclosures}

At this stage, the three general categories (economic impact, social networking impact, and sustainability impact) were analyzed into sub-themes. Nicholls' (2010) work helped us identify 14 sub-themes of fair trade's social impact, and 23 further sub-themes emerged from analyzing the coded statements. While categorizing disclosures via coding, we counted the number of statements, that is, the number of times fair trade organizations made statements under each sub-theme. Figure 1 and Table 2 in section 5 of this paper present the results.

Accordingly, the 3 major themes and 37 sub-themes represent the building blocks or common understandings (i.e. doxa) of fair trade impact. Because the fair trade alliance made major changes in its operating Principles by issuing a Charter in 2009, we categorized statements made in the first four years (2006-9) as 'pre-Charter disclosures' and those made in the next four years (2010-13) as 'post-Charter disclosures'. This division enabled us to compare changes in the disclosures of fair trade organizations on a specific social impact (i.e. subtheme). More specifically, we analyzed: (1) the number of times fair trade organizations made statements under each sub-theme, (2) the emergence of new disclosure sub-themes (i.e. additions) and (3) whether sub-themes disappeared (i.e. deletions) during the pre- and postCharter periods. This comparative analysis helped us to observe how the Charter, as a core symbolic power mechanism, triggered changes to social impact disclosures in the fair trade field. This phase of analysis revealed elements of economic, social, and cultural capital (Bourdieu, 1986) in the composition of the fair trade organizations. 
4.3.4 Analysis of rhetoric and persuasive arguments by fair trade organizations and their stakeholders in light of the adopted theoretical framework

Finally, we analyzed the rhetoric employed by fair trade organizations in social impact disclosures, and the rhetorical and persuasive arguments (for and against fair trade organizations) used by stakeholder groups. As mentioned in section 4.2 of this paper, we tried to identify particular rhetorical features (such as reactions, defensiveness, positive/approving/ appreciative features, negative/disapproving/expressions of concern, silences) to qualitatively analyze both fair trade organizations' rhetorical and silence strategies, and stakeholders' uses of rhetoric and persuasive arguments. This analysis helped us to explore how, as a mechanism of symbolic power, fair trade organizations' communication strategies survive the expression of opposing but partial views (Bourdieu, 1986) by the wider stakeholder community. In other words, the analysis helped us to explore fair trade organizations' hegemonic interest and associated struggles to maintain legitimacy (Bourdieu, 1989). The results of this analysis are presented below.

\section{Findings}

\subsection{Social impact disclosures, rhetoric, and symbolic power of fair trade organizations}

In this section, we analyze social impact disclosures and associated rhetoric as a mechanism of the symbolic power (Bourdieu, 1991) of major fair trade organizations within the UK. In doing this, we also trace different forms of capital (Bourdieu, (1986), which provides an understanding of how fair trade organizations can secure a dominant position in the field. Most importantly, our analysis leads to an understanding of the symbolic power of fair trade organizations amid the tensions, contradictions, and challenges posed by different groups of external stakeholders.

\subsubsection{Social impact disclosures, Charter of Fair Trade Principles, and symbolic power}

By analyzing social impact disclosures by our sample full and partly fair trade organizations over an eight-year period (from 2006 to 2013), this study reveals noticeable changes in such disclosures from 2010 onward. Table 2 presents disclosure sub-themes under three general categories (disclosures of economic impact, social networking impact, and sustainability impact) that emerged in our analysis before and after 2009, demonstrating the 2009 Charter of Fair Trade Principles as a significant driver of changes in the understanding of fair trade at the industry level. The 2009 Charter became the cornerstone of the symbolic power through which fair trade organizations protect their interests. As stated in 4.3.3 above, we identified a total of 37 sub-themes. 
Table 2: Social impact disclosures before and after adoption of the Charter of Fair Trade Principles in 2009

\begin{tabular}{|c|c|c|c|c|c|c|c|c|}
\hline \multirow{2}{*}{$\begin{array}{l}\text { Disclosure } \\
\text { themes }\end{array}$} & \multicolumn{4}{|c|}{ Sub-themes and number of disclosures before 2009} & \multicolumn{4}{|c|}{ Sub-themes and number of disclosures after 2009} \\
\hline & Full fair trade organizations & $\begin{array}{c}\text { No of } \\
\text { disc. }\end{array}$ & $\begin{array}{l}\text { Partly fair trade } \\
\text { organizations }\end{array}$ & $\begin{array}{c}\text { No of } \\
\text { disc. }\end{array}$ & Full fair trade organizations & $\begin{array}{c}\text { No of } \\
\text { disc. }\end{array}$ & Partly fair trade organizations & $\begin{array}{l}\text { No of } \\
\text { disc. }\end{array}$ \\
\hline $\begin{array}{l}\text { Economic } \\
\text { impact }\end{array}$ & $\begin{array}{ll} & \text { Sales growth } \\
\text { - } & \text { Fair trade product } \\
\text { development } \\
\text { - } \quad \text { Understanding market } \\
\text { conditions at both } \\
\text { producer and consumer } \\
\text { ends }\end{array}$ & $\begin{array}{l}103 \\
153 \\
128\end{array}$ & $\begin{array}{ll}\text { - } & \text { Sales growth } \\
\text { - } & \text { Fair trade } \\
& \text { product } \\
\text { development }\end{array}$ & 189 & $\begin{array}{ll}\text { - } & \text { Sales growth } \\
\text { - } & \text { Fair trade product development } \\
\text { - } & \text { Understanding market conditions at both } \\
\text { - } & \text { producer and consumer ends } \\
\text { - } & \text { Improt expansion strategies } \\
\text { - } & \text { Donations to producer communities }\end{array}$ & $\begin{array}{r}196 \\
167 \\
74 \\
\\
54 \\
47 \\
21\end{array}$ & $\begin{array}{ll}- & \text { Sales growth } \\
\text { - } & \text { Fair trade product } \\
\text { development } \\
\text { - } & \text { Market expansion } \\
\text { strategies } \\
\text { - } \\
\begin{array}{l}\text { Donations to producer } \\
\text { communities }\end{array}\end{array}$ & $\begin{array}{l}342 \\
213 \\
114\end{array}$ \\
\hline Total econom & c impact disclosures & 384 & & 299 & & 559 & & 741 \\
\hline $\begin{array}{l}\text { Social } \\
\text { networking } \\
\text { impact }\end{array}$ & $\begin{array}{l}\text { - } \quad \text { Campaigning for } \\
\text { trading justice } \\
\text { - Raising awareness for } \\
\text { producers' } \\
\text { empowerment } \\
\text { - Fair trade certification }\end{array}$ & $\begin{array}{r}154 \\
79 \\
52\end{array}$ & $\begin{array}{ll}\text { - } & \text { Fair trade } \\
\text { certification }\end{array}$ & 210 & $\begin{array}{ll}\text { - } & \text { Campaigning for trading justice } \\
\text { - } & \text { Raising awareness for producers } \\
\text { - } & \text { Fair trade certification } \\
\text { - } & \text { Networking to improve fair trade chain } \\
\text { - } & \text { Deeper engagement with producers } \\
\text { - } & \text { Collaboration for environmental } \\
& \text { protection }\end{array}$ & $\begin{array}{l}179 \\
\\
93 \\
84 \\
77 \\
54 \\
35\end{array}$ & $\begin{array}{ll}\text { - } & \text { Fair trade certification } \\
\text { Networking to improve } \\
\text { fair trade chain }\end{array}$ & 247 \\
\hline Total social $n$ & tworking impact disclosures & 285 & & 210 & & 522 & & 319 \\
\hline $\begin{array}{l}\text { Sustainabilit } \\
\text { y (social } \\
\text { and } \\
\text { environment } \\
\text { al) impact }\end{array}$ & $\begin{array}{ll}\text { - } & \text { Human rights } \\
\text { - } & \text { Empowerment } \\
\text { - } & \text { Sustainable livelihood } \\
\text { - } & \text { Sustainable source of } \\
& \text { raw material } \\
\text { - } & \text { Climate change } \\
\text { - } & \text { Ecological } \\
& \text { sustainability }\end{array}$ & $\begin{array}{r}67 \\
89 \\
61 \\
53 \\
3812 \\
17\end{array}$ & $\begin{array}{ll}\text { - } & \text { Climate change } \\
\text { - } & \text { Ecological } \\
\text { sustainability }\end{array}$ & 281 & $\begin{array}{ll}\text { - } & \text { Human rights } \\
\text { - } & \text { Empowerment } \\
\text { - } & \text { Democratic decision-making } \\
\text { - } & \text { Sustainable livelihood } \\
\text { - } & \text { Children's rights and wellbeing } \\
\text { - } & \text { Disclosing child labor } \\
\text { - } & \text { Freedom of association } \\
\text { - } & \text { Health and safety } \\
\text { - } & \text { Sustainable source of raw material } \\
\text { - } & \text { Efficient use of raw material } \\
\text { - } & \text { Responsible consumption } \\
\text { - } & \text { Climate change } \\
\text { Environmental sustainability }\end{array}$ & $\begin{array}{r}85 \\
103 \\
76 \\
29 \\
42 \\
35 \\
22 \\
8 \\
17 \\
10 \\
18 \\
8 \\
11 \\
12 \\
13\end{array}$ & $\begin{array}{ll}\text { - } & \text { Health and safety } \\
\text { - } & \text { Sustainable source of raw } \\
\text { material } \\
\text { - } & \text { Efficient use of raw } \\
\text { material } \\
\text { - } & \text { Responsible consumption } \\
\text { - } & \text { Elimate change } \\
\text { - } & \text { sustainability } \\
\text { - } & \text { seduced non-renewable } \\
\text { - } & \text { Waste of energy } \\
\text { initiatives }\end{array}$ & $\begin{array}{r}149 \\
20 \\
143 \\
94 \\
25\end{array}$ \\
\hline Total sustaina & ility impact disclosures & 337 & & 586 & & 489 & & 642 \\
\hline
\end{tabular}


Our analysis of social impact disclosures (as illustrated in Table 2) reveals that full fair trade organizations were more likely to position themselves through both economic impact (high sales growth) and social networking impact (e.g. long-term relationships with both regulatory NGO and FLO; deeper engagement with the producer community; campaigning and awareness-raising activities) than partly fair trade organizations. For full fair trade organizations, there were noticeable increases in sales growth disclosures (pre-Charter period: 103 disclosures; post-Charter period: 196 disclosures) and product development disclosures (pre-Charter period: 153 disclosures; post-Charter period: 167 disclosures) along with new subthemes related to economic impact disclosures: market expansion strategies (54 disclosures), improvement in the trade chain (47 disclosures), and donations to producer communities (21 disclosures). Full fair trade organizations demonstrated their increasing interest in social networking impact during the post-Charter period and accordingly they disclosed information on networking to improve fair trade chain (77 disclosures), collaborations with FLO for environmental protection programs (35 disclosures), and deeper engagement with producer community through jointly commissioned programs and research (54 disclosures)). Furthermore, full fair trade organizations provided a wide range of disclosures on the sustainability impact (social and environmental) of fair trade. Interestingly, eight new subthemes emerged during the post-Charter period: democratic decision-making (29 disclosures), children's rights and wellbeing (35 disclosures), disclosing child labor (22 disclosures), elimination of forced labor (8 disclosures), freedom of association (17 disclosures), health and safety (10 disclosures), efficient use of raw material (8 disclosures), and responsible consumption (11 disclosures) reflect the Charter's adoption of International Labor Organization (ILO) Conventions. Such representations emphasized building relationships within the fair trade network, and social and environmental sustainability, by repeating stories and including pictures and diagrams both before and after the emergence of the Charter.

Partly fair trade organizations, however, were more likely to position themselves mainly through economic impact, demonstrated through their consistent emphasis on sales and market expansion strategies. Table 2 shows two sub-themes: sales growth (pre-Charter period: 189; post-Charter period: 342) and product development (pre-Charter period: 110; post-Charter period: 213). During the post-Charter period, two new sub-themes emerged: market expansion strategies (114 disclosures) and donations to producer communities (72 disclosures). Under the social networking category, partly fair trade organizations disclosed one sub-theme: fair trade certification (pre-Charter period: 210 disclosures; post-Charter period: 247 disclosures) and an additional sub-theme, networking to improve fair trade chain (72 disclosures) emerged during the post-Charter period. Partly fair trade organizations' sustainability disclosures (social and environmental) spanned only two sub-themes during the pre-Charter period: climate change (281 disclosures) and ecological sustainability (305 disclosures). Disclosures on both sub-themes reduced after the Charter, to 143 and 94 respectively. However, in the post-Charter period six new sub-themes emerged (health and safety: 122 disclosures; sustainable source of raw material: 68 disclosures; efficient use of raw material: 149 disclosures; responsible consumption: 20 disclosures: reduced use of non-renewable energy: 24 disclosures; and waste management: 21 disclosures) showing an emphasis on sustainability acquainted with the Charter of Fair Trade Principles. 
We also carried out a trend analysis, which reveals noticeable changes in the volume of social impact disclosures from 2010 onward. Figure 1 depicts trends in social impact disclosures from 2006-13 focusing on changes in the number of impact disclosures under each of the three major themes. As Figure 1 shows, full fair trade organizations steadily increased the number of social impact disclosures they made (from 194 disclosures in 2006 to 434 disclosures in 2013) whereas partly fair trade organizations demonstrated a slower increase (from 270 disclosures in 2006 to 548 disclosures in 2013) with fluctuations in economic impact and sustainability impact disclosures over the period of observation.
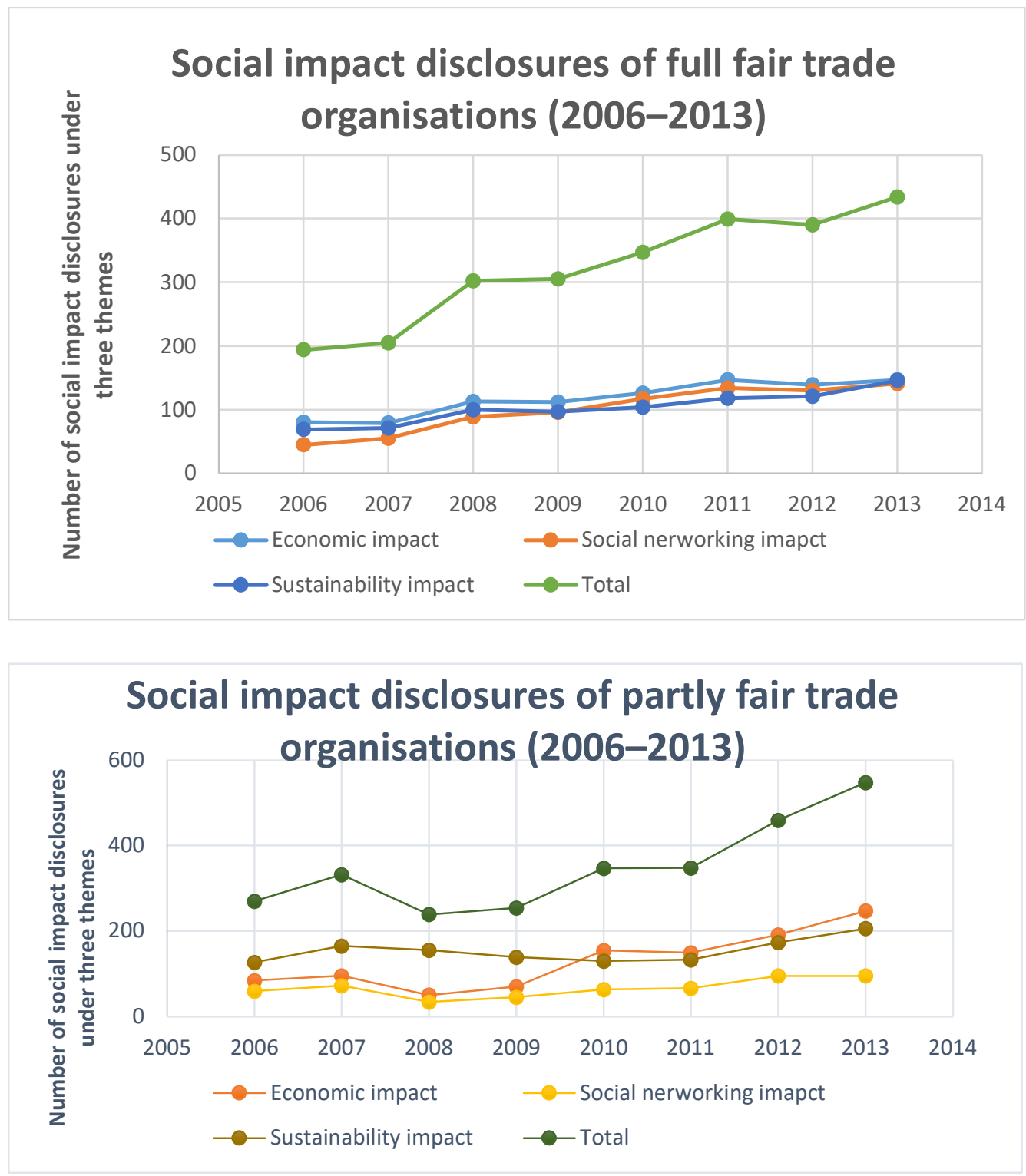

Figure 1: Social impact disclosures of full and partly fair trade organizations (2006-13)

Delving deep into the volume and nature of changes in the disclosure pattern, our analysis reveals how representations of the impact of fair trade changed after the Charter was published in 2009. While the fair trade Charter and its language apparently influenced fair trade organizations to incorporate new social impact themes and increase the volume of disclosures, 
given the wider stakeholder concerns (which will be presented in the next sections), critical accounting scholars may find that legitimation via disclosure practices of these types leaves stakeholder voices neglected (Islam et al., 2018) or perpetuates existing social inequalities (Puxty, 1991). In the next few sub-sections, by drawing on Bourdieu's notion of symbolic power (Everett, 2002; Bourdieu, 1989), this study explores the problems in social impact disclosure practices.

\subsubsection{Persuasive arguments: shaping stakeholders' view of legitimacy in fair trade business practices}

We found that, when fair trade organizations disclosed social impact information, they accompanied it with persuasive text in order to justify their ongoing position. At the same time they were able to manage or persuade a group of stakeholders into uttering positive words about, or endorsing, their impact on society. However, we noticed that another group of stakeholders were critical of fair trade organizations' performance in achieving societal change, which created a level of tension in the fair trade field. In the following sections of this paper, we identify persuasive words used by stakeholders (both positive about and critical of fair trade impacts), as well as the responses of the fair trade organizations, and classify them under the themes and sub-themes we have identified, in an attempt to look into how opposing but partial views become superseded (Bourdieu, 1986). Such comparative analysis helped us to understand how dominant actors shaped the dispositions of different stakeholders. Comparing persuasive texts issued simultaneously by different fair trade actors enabled us to reveal how (re)formulation of the common understanding (doxa) of fair trade took place in the field. Our analysis supports the view that in a particular social field one group achieve dominance over another through ideas, texts, discourses, and practices (Bourdieu, 1986, 1991).

\subsubsection{Stakeholders' persuasive rhetoric: a source of symbolic power}

Our findings indicate that full fair trade organizations received positive evaluations of their social impact from industry associations (such as FLO), academic researchers, NGOs working for human rights and empowerment, media journalists, and general social media users (i.e. consumers). This positive and persuasive appreciation was found both before and after introduction of the Charter in 2009. The persuasive text used by these stakeholders largely focused on these organizations' contribution to expanding the market (efficiency), new product development, initiating the fair trade labelling scheme, campaigning for trading justice, and networking activities. The texts indicate stakeholders' reaffirmation of the accumulation of economic and social capital by full fair trade organizations in the field. The following is an example of a researcher's appreciation of the efficiency of full fair trade organizations in expanding the markets for fair trade products:

While labelling is an important and growing avenue for the commercial retailing of Fair Trade products, the creation of commercially competitive Fair Trade brands like Cafédirect and Divine Chocolate exemplify how innovative [alternative trading organizations] ATOs have been in creating a space in the conventional market for the products of their producer partners. (Valiente-Riedl, 2013, p. 65). 
Sustainability aspects of full fair trade organizations, such as empowering producers, received significant attention during the period studied from academic researchers and different NGOs working for human rights and empowerment. The rhetoric of producer empowerment shows the full fair trade organizations mobilizing symbolic power to strengthen their position in the field:

With Divine, for the first time in the history of chocolate, the farmers that grow the cocoa have a significant share of the wealth they are creating. Divine doesn't just pay a Fair Trade price. Divine also invests $2 \%$ of turnover in a producer support program that has supported their democratic organization and helped them build their business. (ILRF, 2009)

Whilst such positive evaluations from stakeholders enhance the symbolic power of full fair trade organizations, we observe that they took a proactive approach in disseminating them in the news media. The following examples (Figures 2 and 3) demonstrate that Cafédirect have used the news media to recognize (and endorse) stakeholder approval.

\section{Media coverage}

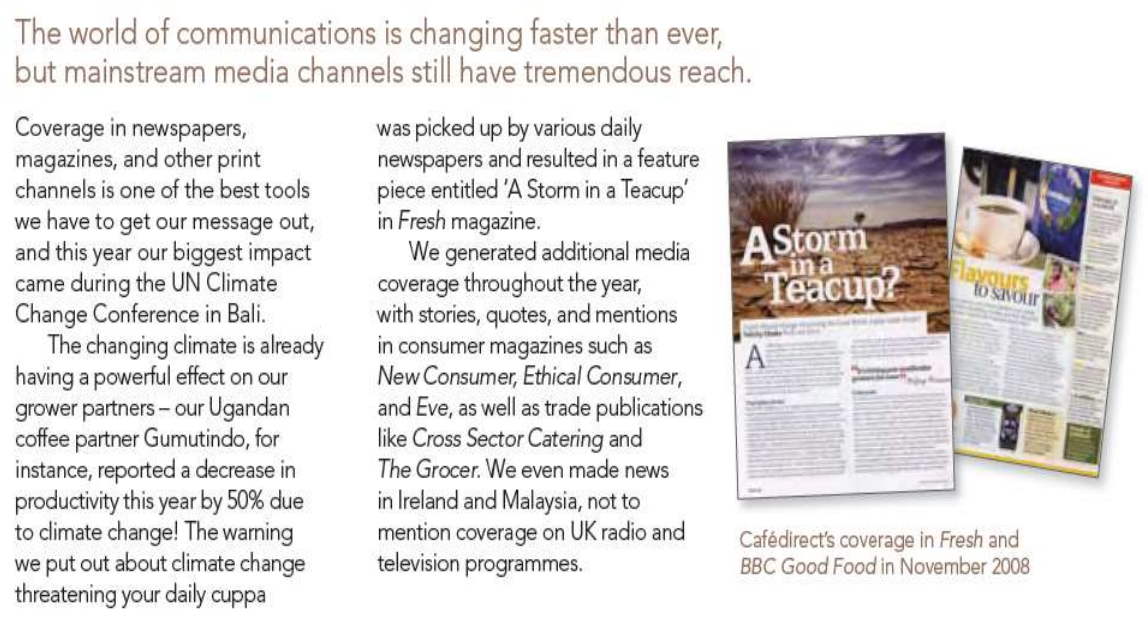

Figure 2. Disclosures in the news media (extract from Cafédirect, Annual Report, 2007/2008).

In the post-Charter period full fair trade organizations started using internet blogs and social media to broadcast their campaigning activities and disseminate stakeholders' positive evaluations. The following example from Traidcraft's blog documents their campaigning initiatives to amend supermarkets' practices within the fair trade chain:

Together we called for a watchdog to investigate abuse of suppliers - and won! In 2013, the government introduced a Groceries Code Adjudicator. This watchdog can now take complaints from direct suppliers of supermarkets, whether in the UK or overseas. Crucially, the office has the power to impose fines on supermarkets - this would not have happened without your campaigning! (Traidcraft, 2015).

Analysis of social media content revealed that full fair trade organizations were more active in disclosing news about new product launches and campaigning activities, whereas social media users mostly responded to new fair trade products coming onto the market. Social media users' excitement at fair trade product launches may be assessed by the number of likes and comments 
in response to news of new products. A recent study demonstrates how 'like' indicates appreciation of particular comments and posts, and can significantly influence organizational responses (Toubiana \& Zietsma, 2017). Accordingly, we considered 'likes' as an expression of appreciation by consumers (i.e. habitus, how fair trade is perceived by them). Such appreciation indicates a flow of symbolic power (Everett, 2002; Bourdieu, 1986, 1989) through which fair trade organizations enhance their economic capital. The following example shows Facebook users' responses to a particular product development disclosure:

Cafédirect: ${ }^{13}$ We think things that are made better, taste better. Which is why we only work directly with expert smallholders to create our award winning range of tea, coffee and hot chocolate. Can you guess what our motto is??

Facebook user (1): Made the little man equal.

Facebook user (2): Made the small way - definitely agree that things made better taste better, certainly true of your coffees :)

Facebook user (3): Made the small way. Your coffee is gorgeous by the way.

Partly fair trade organizations received relatively less support and appreciation from stakeholders than full fair trade organizations. Much of the appreciation that was received came from the regulatory body (FLO) and some news magazines that focus on fair trade news, for expanding the fair trade market, increasing sales, and maintaining trading relationships with fair trade farmers. The following statement was published on the FLO website:

Here's to six years of Fair trade Certified Espresso Roast in Starbucks across the UK! From 21-25 September, Fair trade is celebrating the support Starbucks has given to coffee farmers so they can build a better future for themselves, their families and communities. (Fairtrade Foundation, 2015).

Furthermore, our analysis of news articles over the eight-year period studied indicated that the news media were more inclined to report on market competition, expansion opportunities, and positive social impact remarks by stakeholders after 2009. The following example from a wellknown online UK news magazine, The Grocer, documents the media's appreciation of expansions of fair trade product ranges, leaving the impact on producer communities unaddressed:

A war of words has broken out between Sainsbury's and The Co-operative Group following the launch of a fair trade campaign by the Co-op... Both retailers have pushed fair trade hard. The Co-op Group is the only retailer to have converted all block chocolate and own-label hot beverages to fair trade and has the largest accredited own-label wine range. Sainsbury's converted its entire banana range to fair trade in 2006 and sells more than 800 fair trade products in its stores. (Phillips, 2010).

The article goes on to document remarks from the regulatory body regarding such competition:

${ }^{13}$ Viewed on 20 August 2015. 
The Fairtrade Foundation said it was "very refreshing to see supermarkets striving to lead on ethics rather than price. Both can take credit for leading on fair trade", said policy and communications director Barbara Crowther. (Phillips, 2010).

As partly fair trade organizations were mostly appreciated by FLO, their social impact disclosures also aligned with FLO-related networking activities. On most occasions they remained silent to other stakeholders' remarks. From the symbolic power perspective (Bourdieu, 1989), analysis of positive evaluations by a group of stakeholders enabled us to understand how the rhetoric of stakeholders and fair trade organizations on the positive impact of fair trade intersects and remains powerful, at least symbolically. However, our analysis in the following section will extend our extant understanding and provide insight into how concerns and criticisms by another group of stakeholders are mobilized to create contradictions and challenges in the fair trade field.

\subsubsection{Stakeholders' opposing rhetoric: a challenge to dominant discourse}

Among the documents collected for analysis, this study observed that a group of stakeholders, including some researchers and social media followers, expressed concerns about 'deviant' use of the fair trade label, even though expressions of appreciation by some stakeholders dominate. For example, researchers raised concerns that fair trade certification might hide degradation of producers rather than protecting them:

Certifying plantations alongside small producers is not only an important dilution of one of the founding principles of Fair Trade and one that crucially differentiates Fair Trade from its other, less ambitious ethical rivals. Perhaps more importantly, it also contributes to commodity fetishism. By placing remarkably different conditions of production under the exact same ethical label, Fair Trade is no longer revealing the social and environmental conditions of production, but hiding them. (Hudson, Hudson, \& Fridell, 2013, p. 179).

Similar concerns were raised in social media (Facebook) and news media (see our analysis in section 5.1.3).

While full fair trade organizations faced a level of stakeholder criticism of and concern regarding their practices, partly fair trade organizations faced significantly higher levels of criticism from academic researchers, the media, NGOs, and social media users. Academic researchers raised concerns about the intention behind, as well as the effect of, aggressive market growth, with general concerns raised regarding partial or corporate participation in the fair trade field. Some researchers have addressed the actions of particular partly fair trade organizations being mainstream retailers that may adversely affect environmentally friendly production systems:

Transnational producers (the main suppliers to UK supermarkets) were tasked with sourcing certified bananas, and thus far, the measure to overcome the problem of supply not meeting demand, has been to FLO-certify large plantations operated by the transnational producers. A consequence of which, as noted by Raynolds (2007: p. 74), is the 'corporate mainstreaming' of Fair Trade and the danger of undermining the very principles that it is predicated on. (Robinson, 2009, pp 1020-21). 
This example illustrates the tension and contradictions among fair trade organizations in maintaining their dominance and legitimacy in the face of stakeholder concerns. Concerns were also raised by NGOs, social media (Facebook), and news media.

\subsubsection{Silence in fair trade organizations' responses to stakeholder concerns}

We found fair trade organizations remained silent to stakeholder concerns over injustices (such as negative social and environmental impacts of their activities). The silence from full fair trade organizations in particular provides some insight into symbolic power (Everett, 2002; Bourdieu, 1989). The following example reflects the nature of consumers' concerns about the environmental impact of fair trade. However, it is important to note that, while these organizations generally posted a "Thanks" comment in response to any form of social media appreciation, they remained silent when concerns or confusion were raised by social media followers about the general trading policy described on their official website. For example, the full fair trade organization in the post below did not respond to the social media user's comment:

Traidcraft's Facebook Post: Clean \& Fair is in the building! We're excited to announce that the range will include four products initially; a hand wash, a washing up liquid, a laundry liquid and multi-surface cleaner, staples for any household! All the products in the range contain Fair trade coconut oil and Traidcraft's pioneering FairPalm. All are fragranced with natural essential oils. The range will be available to order from our Online Shop 9am on Thursday 30th January.

Facebook user: How fair is Fairpalm? Or rather, how environmentally sustainable? I am generally suspicious of palm oil in all its manifestations... (See at: www.facebook.com/Traidcraft?fref=ts/. Viewed on 25 August 2015)

Fair trade organizations' non-responsiveness becomes more noticeable where researchers for this study observed web links giving official responses to some stakeholder concerns being deactivated. For example, the BBC's television documentary program Panorama showed violation of an ILO Convention and an incident of child labor in the fair trade chain, where a full and a partly fair trade organization were believed to be involved. The statement below is a quote from the documentary:

Panorama also found that there is no guarantee, despite safeguards, even with chocolate marketed as Fair trade, that child labor - as defined by the International Labor Organization (ILO) - has not been involved in the supply chain... Panorama has seen documents which show that in September 2009, the Fair trade cocoa co-operative in Ghana which supplies Cadbury and Divine, suspended seven out of 33 of their cocoa farming communities in one of its 52 major growing districts in the country after they were found to be using the worst forms of child labor. Following remedial action by Kuapa Kokoo, the fair trade suspension was lifted in early January. The co-operative said it is the only time that it has failed an audit of its farmers' practices with respect to child labor in 15 years as a fair trade supplier. (Kenyon, 2010).

In response to the documentary, neither the named fair trade organizations (Divine Chocolate and Equal Exchange) nor FLO were seen to issue statements on the issue. Our analysis further revealed that full fair trade organizations usually remain silent to concerns at social inequalities in fair trade businesses expressed by stakeholders in social media. Our analysis draws on prior 
accounting research that showed that social inequalities are ingrained in the silence of organizational reporting practices (Chwastiak \& Young, 2003; Young, 2003).

Similar to full fair trade organizations, we observed that partly fair trade organizations usually made limited direct response to concerns raised by academic researchers or general consumers through social media unless such concerns were raised by NGOs affiliated with the fair trade system and received critical media coverage. For example, the following statement from a news article documented complaints by Oxfam International that were picked up by journalists from famous news agency, Agence France Presse:

Accusing Starbucks of being behind the NCA protest, Oxfam said the US chain was denying Ethiopian producers an estimated 47 million pounds (70 million euros, 88.5 million dollars) a year. (Agence France Presse, 2006).

We found an explanatory note in which Starbucks justified the circumstances and the measures they had taken to handle this particular incident (Figure 4). Their disclosure also included a stakeholder comment that affirmed Starbucks' contribution to the particular project.

Even though the above disclosure demonstrates that partly fair trade organizations may have taken corrective steps to address the concerns of NGOs (such as Oxfam International), this form of response was rare. In most cases we found that partly fair trade organizations either did not respond, or their response was inadequate to address the substantive concerns over a lack of measures to improve the lives of the farmers or producers in the developing world.

Our findings on stakeholders' criticisms of fair trade organizations and responses by those organizations shed light on how stakeholders' perceptions are shaped through selective response and silence. We found that partly fair trade organizations faced more criticism than full fair trade organizations regarding the unequal social benefits of fair trade. Such criticism usually came from researchers conducting independent studies and documenting the perceptions of producers and consumers, but some came from journalists and social media users. Partly fair trade organizations mostly remained silent to broader stakeholder concerns regarding the impact of fair trade (similar findings by Young, 2003). Our findings contribute to the growing consensus that silence of social reporting even creates inequality (Young, 2003), by providing insights into the role of silence in maintaining hegemonic relations with stakeholders in the fair trade field. Other studies, such as Preston, Cooper, \& Coombs (1992), and Perez \& Robson (1999), are important and related, as they found that internal contradictions, organizational hypocrisy, and fabrication in organizational reporting (either internal such as budgeting, or external such as social reporting) are ingrained in the creation of corporate legitimacy and perpetuating social inequality. Accordingly, we found that the concerns of stakeholders over existing social inequities in fair trade practices largely remained unaddressed unless they were raised by NGOs and received wide media coverage. Our findings provide important insights into how both full and partly fair trade organizations rely upon ignoring injustices "in order to make profit appear to be an unproblematic measure of success" (Chwastiak \& Young, 2003, p. 548). 
upportunnty to vulu aliu sustan! urel vusmiesses.

In short, these relationships must be mutually beneficial. They must also be collaborative in nature in order to advance measures and practices that contribute to the sustainable production of highquality coffee - and sustainable livelihoods for farmers and their families.

In 2007 these principles were tested, and, in the end, it led to some valuable lessons. The situation concerned a disagreement over the Ethiopian government's efforts to trademark certain Ethiopian coffee designations.

\section{Learning from Our Experience in Ethiopia}

During 2006 and into 2007, Starbucks became involved in a complex discussion with the Ethiopian government regarding their efforts to gain trademark rights for the specialty coffee designations for Sidamo, Harrar and Yirgacheffe. The Ethiopian government hoped that by forming alliances with companies like Starbucks, they would be able to expand the branding and marketing of Ethiopia's world-renowned fine coffees in order to help achieve better prices for their farmers. While we initially felt that other established approaches might work better than trademarking, we have always felt that we shared a common goal with the government to improve the livelihoods of Ethiopian coffee farmers and their communities.

Unfortunately our differences in approach overshadowed our areas of agreement, and toward the end of 2006 and into 2007 the trademark issue became the subject of an Oxfam campaign. News headlines picked up on our differences and characterized the situation as a heated dispute between Starbucks and the Ethiopian government.

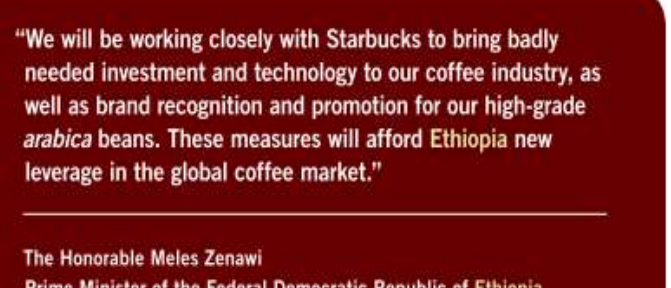

the Ethiopian government, we always shared an interest in supporting Ethiopian farmers. We now have an extraordinary opportunity to continue to partner with the Ethiopian coffee community to support their efforts to produce some of the world's finest coffees."

\section{Howard Schultz}

Starbucks chairman, president and ceo

\begin{abstract}
Although we strongly believe that issues or disagreements are best approached through open and direct dialogue, it did not happen immediately in this case. Initially Starbucks and the Ethiopian government attempted to work with third parties. Once we actually sat down to talk with the Ethiopian government we were able to start a constructive dialogue. During this process, we asked for their input and honest feedback, and provided them with ours. We gained an expanded perspective beyond the business and legal approach we had previously taken. It was direct engagement that proved most helpful in resolving the issue.

In June 2007, Starbucks and the Ethiopian government signed a distribution, marketing and licensing agreement that provides a framework for us to promote jointly the Harrar, Sidamo and Yirgacheffe designations, and to strengthen the Ethiopian coffee sector. It also includes the license of Ethiopia's specialty coffee designations where they may be recognized as trademarks, and establishes a framework for their use when they are not.It's important to us that we continue to learn and grow from this experience. We have carefully examined our actions and decisions related to this issue. Input and feedback have also been gathered from a variety of the parties involved, including Oxfam and the Ethiopian government. We hope this leads to more constructive engagement in the future, especially when differences of opinion or approach arise.
\end{abstract}

Starbucks will continue to provide support for Ethiopia's farmers through a number of avenues. In addition to purchasing and promoting high-quality Ethiopian coffees, we will be opening an Ethiopian-based Farmer Support Center in 2008.

Figure 4. Extract from Starbucks, CSR Report, 2007.

\subsection{The role of FLO and the symbolic power of fair trade organizations}

At the industry level, a significant driver of changes in themes and narratives was the development of the Charter of Fair Trade Principles in 2009. Adoption of these principles therefore indicates a form of the symbolic power (Everett, 2002) of fair trade organizations through which they maintain their dominance and legitimacy. As we saw before (Table 2), 14 new themes and narratives for full fair trade organizations and 9 new themes for partly fair trade organizations emerged during the post-Charter disclosure period. The role of FLO in creating new themes and narratives within the fair trade field was pronounced. We discuss below the role of FLO in maintaining the symbolic power of fair trade organizations through the rhetoric and persuasive discourse it employs.

Our analysis reveals that social impact disclosures by full fair trade organizations appeared more appealing to FLO than those by partly fair trade organizations. In fact, FLO has recognized specific disclosure by fair trade organizations as a legitimate and reputationbuilding practice. For example, the full fair trade organization Twin and Twin Trading provided an assessment of ecosystem services that it commissioned jointly with other research bodies, 
including the Knowledge Transfer Network, the Natural Environmental Research Council, and the Natural Resource Institution of the University of Greenwich. This assessment was reported (or reproduced) by FLO as one of its commissioned research studies. Similarly, an assessment of gender justice within the fair trade chain, jointly conducted by Twin and Twin Trading, Equal Exchange Trading, Divine Chocolate, and the Fair Trade Foundation, was reported by FLO through its Monitoring Scope and Benefits Report, 2013. Such mutual disclosures by fair trade alliance members (both full and partial) indicate how they authenticate each other's reporting practices in the fair trade field. The symbolic power of fair trade organizations is preserved in the fair trade field with the help of the industry regulatory body, FLO.

Social impact disclosures became a key symbolic power of FLO to strengthen its support to both full and partly fair trade organizations. FLO has introduced new accounting, reporting, and legitimation processes, which have been documented by Semeen, Islam, \& Quayle (2016). While Semeen et al. (2016) focused on FLO's social accounts and disclosures, in this paper we have extended that study by examining persuasive narratives (rhetoric) associated with the FLO's social accounts and disclosures and exploring how FLO's activities created a platform to perpetuate domination and the symbolic power of its affiliated full and partly fair trade organizations.

The FLO commissioned a group of researchers and stakeholders to support it in upholding the fair trade agenda. Our analysis reveals that FLO enjoyed favorable notice from researchers and journalists for introducing the labelling scheme that differentiates fair trade products from other products and visibly contributes to sales growth; see the following quotation:

The development of the FAIR TRADE Mark not only offered the customer a simple shorthand, implicitly communicating proof of audit accreditation, it also opened up major new distribution opportunities by providing retailers with a credible and recognizable vehicle through which to focus and deliver on their own ethical credentials. (Bowes, 2011, p. 5)

Although evaluations of the performance of FLO and the fair trade system by some researchers and journalists have been generally favorable, a group of academic researchers, NGOs that collaborate with ILO such as the ILRF, and a group of journalists interested in independent research findings on fair trade subjects raised particular concerns regarding fair trade practices. Independent researchers raised concerns about FLO's governance structure and its fair trade commitments:

The conflict within the FT movement points to the contradiction between the movement's need simultaneously to liberalize and to regulate in order to achieve its collectively agreed upon goal, and ultimately points to the limitations for the movement's expansion. The expansion of the FT movement depends on increased market orientation. But the movement's primary objective is to counter marketization. The further market orientation necessary for expansion contradicts the principles of embeddedness at the centre of the movement(Shorette, 2010-11, p. 478).

In this view, the participation of corporations in fair trade was more controversial. Concerns raised by researchers and stakeholders appeared to be a means of persuading the fair trade organizations to review their social and ethical values (Brennan \& Markl-Davies, 2014) and reinforce hegemony (Bourdieu, 1991). At the same time, stakeholders' rhetoric directly 
challenges the profit which is openly celebrated (Chwastiak \& Young, 2003) in the fair trade field.

A group of journalists used particular rhetoric to express concern about lack of transparency in fair trade certification systems and the consequent social inequities within the fair trade field. Fair trade practices were held to be ineffective in preserving labor rights, children's rights, and gender justice:

If it says fair trade on the box, or certified by the Rainforest Alliance or the Ethical Tea Partnership, it makes no difference: the worker received the same basic cash payment -89 rupees (£1) a day, a little over half the legal wage for an unskilled worker in Assam of 158.54 rupees... But there is a price for keeping wages so low, and it is paid by the workers who cannot afford to keep their daughters. When the traffickers come knocking, offering to take the girls away, promising good wages and an exciting new life, they find it hard to say no... (Chamberlain, 2013).

We found that, in response to growing concerns over fair trade practices under FLO supervision, as well as some limitations in the governance system to handle pressure from external stakeholders, FLO initiated a number of changes in its reporting media, especially after 2008. This was reflected in FLO's general and specific responses to stakeholders' concerns. ${ }^{14}$ It collaborated with research institutes to provide specific responses to them. To date, these collaborations have produced a stream of research reports that have investigated different issues associated with the impact of fair trade, as well as FLO's responses to those reports. The commissioned research mostly identified positive impacts of fair trade. While it also identified shortcomings (some methodological) of the fair trade model, it chiefly defended the model by discussing the limitations of mainstream (or traditional) economic models and highlighting more positive news about fair trade (Lyall, 2014).

While FLO acknowledged that the findings of the commissioned research were "unique and enlightening" and provided some important insights into fair trade practices in a particular context, it did not clarify publicly whether and to what extent it agreed with the identified limitations of present practices and what measures regulatory bodies were going to take to ensure social justice. Any injustices (if any) created out of the existing system of fair trade were silenced by the dominant discourse of positive economic impacts (Chwastiak \& Young, 2003; DeLamotte, 1998). FLO placed more emphasis on developing the market and the network as a way to improve the existing trading system. Despite this, from 2009 onwards FLO made major changes to the structure of its annual reports and monitoring scope and benefit reports (i.e. social audit reports on producers' lives and environmental sustainability, usually with favorable findings) and also opened social media accounts to share its latest news. In these accounts stakeholders' direct concerns over fair trade practices largely remained disregarded. For

\footnotetext{
${ }^{14}$ As discussed earlier in this paper, in 2009 FLO undertook a major reconstruction of the principles of the fair trade system in conjunction with another fair trade regulatory body, WFTO. The reconstruction introduced, via the new Charter, significant changes into the overall social mission of fair trading by integrating and enhancing the cultural, social, and even symbolic practices of both regulatory networks.
} 
example, success stories about Malawi were repeatedly disclosed in monitoring reports from 2012, 2013, and 2014, along with a commissioned research study published in 2011, while some direct stakeholder concerns (as mentioned earlier) over the impact of fair trade remained unattended-to. Over-emphasis of the positive impacts of fair trade by FLO in fact allowed it to ignore "more easily the distasteful and objectionable aspects of the systems in which we live" (Chwastiak \& Young, 2003, p. 535).

FLO's silence in response to stakeholder concerns over social injustice is also noticeable in its social media postings. Since 2009 FLO's Facebook account has increasingly published news about the organization. The posts and comments on its pages provide useful insights into FLO's mode of response to stakeholders. We observed that FLO actively responded to approval or persuasive positive evaluations from social media followers but rarely responded to their concerns. In some cases FLO defended its certified fair trade organizations' business activities by invoking the scope of their certification. More specifically, FLO frequently referred to the involvement of new partly fair trade actors in the field as a sign of development, but defended stakeholders' criticism of such actors' fair trade practices by referring to the limited scope of their product certification scheme. FLO faced challenges, contradictions, and threats to legitimacy when stakeholders (or social media followers) directly criticized its initiatives to engage corporate actors (partly fair trade organizations) in the fair trading and certification scheme. The following example shows how it avoided concern over injustices in the existing fair trade system:

Social media user: ... they [a fair trade outlet] sell Fair-trade products in same shop that uses unpaid workers. That couldn't be right?

FLO's response: ${ }^{15}$ It's important to remember that Fair trade is a product certification, we do not certify company. Fair trade's mission is to create opportunities for producers in developing countries to improve their working and living conditions. Of course it is important that those companies who sell Fair trade products also have decent working conditions, but this is outside our mandate.

FLO's limited responsibility creates tension, contradictions, and threats to its own legitimacy. As concerns over the transparency of the fair trade labelling scheme, the existence of inequities in labor rights, and the controversial role of partly fair trade organizations were evident in social media posts, FLO's symbolic power was largely ingrained in the positive evaluations of full fair trade organizations by a group of stakeholders. In line with Chwastiak and Young (2003), we found that social media posts by FLO rely upon the ignoring of social injustices and use rhetorical strategies in its statements about social impact to express its point of view and thereby persuade social media users to accept its perspective.

\footnotetext{
${ }^{15}$ See at: www.facebook.com/fair trade?fref=ts. Viewed on 25 August 2015.
} 


\section{Concluding remarks}

This study investigates and identifies problems in social impact disclosure practices and the associated rhetoric of two different groups of fair trade organizations in the UK: full fair trade organizations and partly fair trade organizations (or mainstream retailers) during the period from 2006 to 2013. Using Bourdieu's notion of symbolic power (Bourdieu, 1989), our study illuminates the use of social impact disclosures as a mechanism of the symbolic power of fair trade organizations through which they shape the dominance of fair trade practice in the public domain. In other words, in line with Bourdieu's notion and by relying on three features of organizational communication - social impact disclosures, rhetoric related to disclosures and persuasive arguments (those deployed both by dominators and by the dominated), and silence in reporting - this study shows that fair trade organizations perpetuate hegemony by disregarding stakeholders' direct concerns over a lack of measures to improve the lives of the farmers or producers in the developing world.

To explore the use of rhetoric associated with social impact disclosures we looked at persuasive arguments by both fair trade organizations and stakeholders and revealed conflicts surrounding social injustices by fair trade organizations and resistance to those conflicts. A group of stakeholders, including researchers who conducted commissioned studies, collaborating NGOs, and a group of journalists who covered FLO's latest news, expressed a general form of trust in the fair trade system and the impact of the business operations of full fair trade organizations on improving the livelihoods of producers in developing nations. Such support by a group of stakeholders represents symbolic power through which fair trade organizations protect their dominant interest. However, another group of stakeholders, including independent researchers, other NGOs, and journalists writing for well-known newspapers, was concerned that the existing fair trade system is not effective at ameliorating prevailing social inequalities and, more importantly, that in practice some partly fair trade organizations in this field deviate from the Fair Trade Principles. Moreover, some full fair trade organizations were associated with stakeholders' persuasive concerns over deviant practices of these kinds. Amid such concern among stakeholders, fair trade organizations in general faced a level of challenge to their perpetuation of hegemony.

We also examined the use of silences in organizational reporting and observed that both types of fair trade organization maintained 'silence' when stakeholders voiced concerns in academic literature, news articles, and social media. Fair trade organizations employed rhetorical strategies - shaping the texts of the dominant discourse of social impacts to express their point of view and thereby persuade readers to accept their perspective alone. This finding extends previous research on silencing and the strategic use of accounts and disclosures (Chwastiak \& Young, 2003).

The role of the fair trade regulatory body, FLO, was interesting, as FLO took a dominant role to protect the interests and legitimacy of fair trade organizations. The way it persuaded stakeholders to say good things about fair trade in general and the way it highlighted stakeholders' praise for the impacts of fair trade provides important insights into FLO's attempts to protect the symbolic power of both full and partly fair trade organizations. Like 
individual fair trade organizations, FLO, while emphasizing favorable evaluations by stakeholders, avoided responding to stakeholders' confusions and concerns about, and criticisms of, injustices within the fair trade field. While such findings suggest mechanisms by which the fair trade movement, either intentionally or unintentionally, fosters symbolic violence (Bourdieu, 1989; Everett, 2002), this also suggests that complaints about injustices ingrained in current systems of fair trade may be silenced by being ignored by the dominant party (Chwastiak \& Young, 2003).

Our research is the extension of previous accounting research (Dey, 2007; Gray et al., 1997), and contributes to the literature through investigation of how fair trade organizations use social impact disclosures and maintain symbolic power in the field of fair trade. Our study advances a critical argument beyond accounting literature (Nicholls, 2010), that the public discourses of the fair trade system serve as a symbolic power that is disconnected from the voices of its stakeholders. Underpinned by Bourdieu's notion of symbolic power (Bourdieu, 1989), our research contributes to accounting literature on silence and rhetorical strategies in organizational reporting (Chwastiak \& Young, 2003; Young, 2003) by showing that fair trade organizations use silence and rhetorical strategies associated with their social impact disclosures in order to disregard stakeholders who are critical of their practices. Such research is important for understanding hegemony and the contradictions that arise in maintaining legitimacy in fair trade organizations that form under the banner of social equity principles. Our research offers important critical insight that may be useful for social activists, policy makers, academic researchers, and other stakeholders working for the development of fair trade organizations.

Nevertheless, our study is not exhaustive. Like many other qualitative studies in accounting, our study dealt with an under-developed theoretical concept and a new range of data sources. Our analysis focuses on a particular fair trade alliance and historical data within a limited timeframe (2006-13). Our findings do not represent social impact disclosures outside this period. While our focus was FLO and its affiliated fair trade organizations, we did not examine the role of other fair trade regulatory bodies (e.g. WFTO) and their members in shaping the legitimate vision of fair trade. We considered the availability of disclosures in the public domain when selecting the organizations to be studied. This was because we focused on stakeholder relations and the contested legitimacy of fair trade organizations as reflected in the public domain. Accordingly, to overcome the potential for self-selection bias, we reviewed relevant articles in broader social science fields and analyzed expectations and concerns expressed by stakeholders in conjunction with disclosures. In relation to Bourdieu's theoretical framing, to enhance our understanding of stakeholders' concerns and expectations beyond their public statements, we call for further research that embraces other methods, such as interviews with managers and stakeholders. 


\section{References}

Agence France Presse. (2006, 27 October 2006). Starbucks in storm in a coffee cup over Ethiopian trademark bid Agence France Presse, p. 15.

Andon, P., \& Free, C. (2012). Auditing and crisis management: The 2010 Melbourne Storm salary cap scandal. Accounting, Organizations and Society, 37(3), 131-154. doi: 10.1016/j.aos.2012.01.004

Archel, P., Husillos, J., Larrinaga, C., \& Spence, C. (2009). Social disclosure, legitimacy theory and the role of the state. Accounting, Auditing \& Accountability Journal, 22(8), 1284-1307. doi: doi:10.1108/09513570910999319

Archel, P., Husillos, J., \& Spence, C. (2011). The institutionalisation of unaccountability: Loading the dice of Corporate Social Responsibility discourse. Accounting, Organizations and Society, 36(6), 327-343. doi: 10.1016/j.aos.2011.06.003

Arrington, C. E., \& Puxty, A. G. (1991). Accounting, interests, and rationality: a communicative relation. Critical Perspectives on Accounting, 2(1), 31-58. doi:10.1016/1045-2354(91)900189

Beattie, V. (2014). Accounting narratives and the narrative turn in accounting research: Issues, theory, methodology, methods and a research framework. British Accounting Review, 46(2), 111-134. doi: 10.1016/j.bar.2014.05.001

Bebbington, J., \& Larrinaga, C. (2014). Accounting and sustainable development: An exploration. Accounting, Organizations and Society. doi: 10.1016/j.aos.2014.01.003

Bebbington, J., Larrinaga, C., \& Moneva, J. M. (2008). Corporate social reporting and reputation risk management. Accounting, Auditing \& Accountability Journal, 21(3), 337-361. doi: $10.1108 / 09513570810863932$

Belal, A., \& Owen, D. L. (2015). The rise and fall of stand-alone social reporting in a multinational subsidiary in Bangladesh: A case study. Accounting, Auditing \& Accountability Journal, 28(7), 1160-1192. doi: 10.1108/AAAJ-08-2013-1443

Bennett, E. A. (2016). Who Governs Socially-Oriented Voluntary Sustainability Standards? Not the Producers of Certified Products. World development(91), 53-69.

Benston, G. J. (1982). Accounting and corporate accountability. Accounting, Organizations and Society, 7(2), 87-105.

Birkey, R. N., Guidry, R. P., Islam, M. A., \& Patten, D. M. (2016). Mandated Social Disclosure: An Analysis of the Response to the California Transparency in Supply Chains Act of 2010. Journal of Business Ethics, 1-15. doi: 10.1007/s10551-016-3364-7

Blowfield, M., \& Dolan, C. (2010). Fairtrade Facts and Fancies: What Kenyan Fairtrade Tea Tells us About Business' Role as Development Agent. Journal of Business Ethics, 93(2), 143-162. doi: 10.1007/s10551-010-0558-2

Bourdieu, P. (1986). The Forms of Capital. In J. G. Richardson (Ed.), Handbook of Theory and Research for the Sociology of Education (pp. 279-791): Greenwood Publishing Group.

Bourdieu, P. (1989). Social space and symbolic power. Sociological theory, 7(1), 14-25. doi: $10.2307 / 202060$

Bowes, J. (2011). The fair trade revolution (1 ed.). London: Pluto.

Brennan, N. M., \& Merkl-Davies, D. M. (2014). Rhetoric and argument in social and environmental reporting: the Dirty Laundry case. Accounting, Auditing \& Accountability Journal, 27(4), 602-633. doi: 10.1108/AAAJ-04-2013-1333

Brown, N. and Deegan, C., (1998). The public disclosure of environmental performance information - a dual test of media agenda setting theory and legitimacy theory. Accounting and business research, 29(1), pp.21-41.

Campbell, D., (2003). Intra-and intersectoral effects in environmental disclosures: evidence for legitimacy theory?. Business Strategy and the Environment, 12(6), pp.357-371.

Chamberlain, G. (2013, 21 July 2013). How poverty wages for tea pickers fuel India's trade in child slavery, The Guardian. Retrieved from http://www.theguardian.com/world/2013/jul/20/poverty-tea-pickers-india-child-slavery 
Cho, C. H., Michelon, G., Patten, D. M., \& Roberts, R. W. (2015). CSR disclosure: the more things change...? Accounting, Auditing \& Accountability Journal, 28(1), 14-35. doi: 10.1108/AAAJ12-2013-1549

Chwastiak, M., \& Young, J. J. (2003). Silences in annual reports. Critical perspectives on accounting, 14(5), 533-552. doi: 10.1016/S1045-2354(02)00162-4

Conway, S. L., O'Keefe, P. A., \& Hrasky, S. L. (2015). Legitimacy, accountability and impression management in NGOs: the Indian Ocean tsunami. Accounting, Auditing \& Accountability Journal, 28(7), 1075-1098. doi: 10.1108/AAAJ-04-2012-01007

Cooper, C. and Joyce, Y., (2013). Insolvency practice in the field of football. Accounting, organizations and society, 38(2), pp.108-129.

Cooper, C., Coulson, A., \& Taylor, P. (2011). Accounting for human rights: Doxic health and safety practices - The accounting lesson from ICL. Critical perspectives on accounting, 22(8), 738758. doi: $10.1016 /$ j.cpa.2011.07.001

Cooper, S., \& Pearce, G. (2011). Climate change performance measurement, control and accountability in English local authority areas. Accounting, Auditing \& Accountability Journal, 24(8), 1097-1118. doi: 10.1108/09513571111184779

Cooper, S. M., \& Owen, D. L. (2007). Corporate social reporting and stakeholder accountability: The missing link. Accounting, Organizations and Society, 32(7-8), 649-667. doi: 10.1016/j.aos.2007.02.001

Davison, J. (2008). Rhetoric, repetition, reporting and the "dot. com" era: words, pictures, intangibles. Accounting, Auditing \& Accountability Journal, 21(6), 791-826.

Deegan, C. (2002). The legitimising effect of social and environmental disclosures -- a theoretical foundation. Accounting, Auditing \& Accountability Journal, 15(3), 282. doi: $10.1108 / 09513570210435852$

Deegan, C., (2002). The legitimising effect of social and environmental disclosures-a theoretical foundation. Accounting, Auditing \& Accountability Journal, 15(3), pp.282-311.

Deegan, C., \& Blomquist, C. (2006). Stakeholder influence on corporate reporting: An exploration of the interaction between WWF-Australia and the Australian minerals industry. Accounting, Organizations and Society, 31(4), 343-372. doi: 10.1016/j.aos.2005.04.001

Deegan, C., \& Islam, M. A. (2010). Media pressures and corporate disclosure of social responsibility performance information: a study of two global clothing and sports retail companies. Accounting and business research, 40(2), 131-148. doi: 10.1080/00014788.2010.9663388

DeLamotte, E. C. (1998). Places of Silence, Journeys of Freedom: The Fiction of Paule Marshall: University of Pennsylvania Press.

Dey, C. (2007). Social accounting at Traidcraft plc: A struggle for the meaning of fair trade. Accounting, Auditing \& Accountability Journal, 20(3), 423. doi: $10.1108 / 09513570710748571$

Dumay, J., \& Hossain, M. A. (2018). Sustainability risk disclosure practices of listed companies in Australia. Australian Accounting Review.

Eagleton, T., \& Bourdieu, P. (1992). Doxa and common life. New Left Review, 191, 111-121. Retreived from http://newleftreview.org/static/assets/archive/pdf/NLR18707.pdf

Everett, J. (2002). Organizational research and the praxeology of Pierre Bourdieu. Organizational Research Methods, 5(1), 56-80. doi: 10.1177/1094428102051005

Everett, J., \& Jamal, T. B. (2004). Multistakeholder Collaboration as Symbolic Marketplace and Pedagogic Practice. Journal of Management Inquiry, 13(1), 57-78. doi: $10.1177 / 1056492603261042$

Everett, J., Neu, D., \& Rahaman, A. S. (2007). Accounting and the global fight against corruption. Accounting, Organizations and Society, 32(6), 513-542. doi: 10.1016/j.aos.2006.07.002

Fairtrade Foundation. (2015). Fairtrade. The power is in your hands. Retrieved from http://www.fairtrade.org.uk/

Fairtrade Foundation. (2019). Who we are. Retrieved from http://www.fairtrade.org.uk/What-isFairtrade/Who-we-are

Fairtrade International. (2015-2016). Annual report.

Fairtrade International (2018-2019). Annual report.Fairtrade International. (2017). About Fairtrade.

Retreived from http://www.fairtrade.net/about-fairtrade.html 
Farjaudon, A.-L., \& Morales, J. (2013). In search of consensus: The role of accounting in the definition and reproduction of dominant interests. Critical perspectives on accounting, 24(2), 154-171. doi: 10.1016/j.cpa.2012.09.010

Gandenberger, C., Garrelts, H., \& Wehlau, D. (2011). Assessing the Effects of Certification Networks on Sustainable Production and Consumption: The Cases of FLO and FSC. Journal of Consumer Policy, 34(1), 107-126. doi: 10.1007/s10603-011-9155-8

Gallhofer, S. and Haslam, J., (1997). The direction of green accounting policy: critical reflections. Accounting, Auditing \& Accountability Journal, 10 (2), pp. 148-174.

Gracia, L. and Oats, L., (2012). Boundary work and tax regulation: A Bourdieusian view. Accounting, Organizations and Society, 37(5), pp.304-321.

Gray, R., (2010). Is accounting for sustainability actually accounting for sustainability... and how would we know? An exploration of narratives of organisations and the planet. Accounting, organizations and society, 35(1), pp.47-62.

Gray, R. (2002). The social accounting project and Accounting Organizations and Society Privileging engagement, imaginings, new accountings and pragmatism over critique? Accounting, Organizations and Society, 27(7), 687-708. doi: 10.1016/S0361-3682(00)00003-9

Gray, R., Dey, C., Owen, D., Evans, R., \& Zadek, S. (1997). Struggling with the praxis of social accounting: Stakeholders, accountability, audits and procedures. Accounting, Auditing \& Accountability Journal, 10(3), 325-364. doi: 10.1108/09513579710178106

Hudson, I., Hudson, M., \& Fridell, M. (2013). Fair trade, sustainability and social change: Palgrave Macmillan.

Hutchens, A. (2009). Changing Big Business: The Globalization of the Fair Trade Movement: Edward Elgar Publishing.

Huybrechts, B., \& Nicholls, A. (2013). The role of legitimacy in social enterprise-corporate collaboration. Social Enterprise Journal, 9(2), 130-146. doi: 10.1108/SEJ-01-2013-0002

ILRF. (2009). Divine Chocolate Leads as Catalyst for Change in Chocolate Market, International Labour Rights Forum. Retrieved from

http://news.prnewswire.com/DisplayReleaseContent.aspx?ACCT=104\&STORY=/www/story 103-03-2009/0004982488\&EDATE=

Islam, M. A., \& Deegan, C. (2008). Motivations for an organisation within a developing country to report social responsibility information: Evidence from Bangladesh. Accounting, Auditing \& Accountability Journal, 21(6), 850-874. doi: 10.1108/09513570810893272

Islam, M. A., \& Deegan, C. (2010). Media pressures and corporate disclosure of social responsibility performance information: A study of two global clothing and sports retail companies. Accounting and business research, 40(2), 131-148. doi: 10.1080/00014788.2010.9663388

Islam, M. A., Deegan, C., \& Gray, R. (2018). Social compliance audits and multinational corporation supply chain: evidence from a study of the rituals of social audits. Accounting and business research, 1-35.

Islam, M. A., \& van Staden, C. J. (2018). Social movement NGOs and the comprehensiveness of conflict mineral disclosures: evidence from global companies. Accounting, Organizations and Society, 65, pp. 1-19.

Jaffee, D. (2010). Fair trade standards, corporate participation, and social movement responses in the United States. Journal of Business Ethics, 92(S2), 267-285. doi: 10.1007/s10551-010-0583-1

Jaffee, D., \& Howard, P. H. (2010). Corporate cooptation of organic and fair trade standards. Agriculture and Human Values, 27(4), 387-399. doi: 10.1007/s10460-009-9231-8

Kenyon, P. (2010, 24 March, 2010). Tracing the bitter truth of chocolate and child labour, Panorama, $B B C$ News.

Killian, S., \& O'Regan, P. (2016). Social accounting and the co-creation of corporate legitimacy. Accounting, Organizations and Society, 50, 1-12. doi: 10.1016/j.aos.2016.02.004

Laine, M. (2009). Ensuring legitimacy through rhetorical changes?: A longitudinal interpretation of the environmental disclosures of a leading Finnish chemical company. Accounting, Auditing \& Accountability Journal, 22(7), 1029-1054. doi: doi:10.1108/09513570910987367

Lanis, R. and Richardson, G., (2013). Corporate social responsibility and tax aggressiveness: a test of legitimacy theory. Accounting, Auditing \& Accountability Journal, 26 (1), pp. 75-100. 
Loconto, A. (2015). Can certified-tea value chains deliver gender equality in Tanzania? Feminist Economics, 21(3), 191-215.

Lyall, A. (2014, January, 2014). Assessing the Impacts of Fairtrade on Worker Defined Forms of Empowerment on Ecuadorian Flower Plantations. Retrieved from http://www.maxhavelaar.ch/fileadmin/user_upload/news/140212-Worker-EmpowermentEcuador-Flower-Plantations-final.pdf

Martinez, D. E., \& Cooper, D. J. (2017). Assembling international development: Accountability and the disarticulation of a social movement. Accounting, Organizations and Society. doi: 10.1016/j.aos.2017.02.002s

Merkl-Davies, D. M., Brennan, N. M., \& McLeay, S. J. (2011). Impression management and retrospective sense-making in corporate narratives: A social psychology perspective. Accounting, Auditing \& Accountability Journal, 24(3), 315-344. doi: doi:10.1108/09513571111124036

Miles, M. B., Huberman, A. M., \& Saldaña, J. (2014). Qualitative data analysis: a methods sourcebook. Thousand Oaks, Califorinia: SAGE Publications, Inc.

Milne, M.J., (2002). Positive accounting theory, political costs and social disclosure analyses: a critical look. Critical perspectives on accounting, 13(3), pp.369-395.

Mobus, J. L. (2005). Mandatory environmental disclosures in a legitimacy theory context. Accounting, Auditing \& Accountability Journal, 18(4), 492. doi: 10.1108/09513570510609333

Moore, G. (2004). The Fair Trade Movement: Parameters, Issues and Future Research. Journal of Business Ethics, 53(1/2), 73-86. doi: 10.1023/B:BUSI.0000039400.57827.c3

Neu, D., (2006). Accounting for public space. Accounting, Organizations and Society, 31(4-5), pp.391-414.

Neu, D., Cooper, D.J. and Everett, J., (2001). Critical accounting interventions. Critical perspectives on accounting, 12(6), pp.735-762.

Neu, D., Ocampo Gomez, E., Graham, C., \& Heincke, M. (2006). "Informing” technologies and the World Bank. Accounting, Organizations and Society, 31(7), 635-662. doi: 10.1016/j.aos.2005.07.002

Nicholls, A. (2009). 'We do good things, don't we?': 'Blended Value Accounting' in social entrepreneurship. Accounting, Organizations and Society, 34(6), 755-769. doi: 10.1016/j.aos.2009.04.008

Nicholls, A. (2010). What Gives Fair Trade Right to Operate? Organizational Legitimacy and Strategic Management. In K. M. Macdonald, Shelley (Ed.), Fair Trade Corporate Accountability and Beyond: Experiments in Global Justice (pp. 114-137): Ashgate Publishing Ltd.

Nicholls, A., \& Opal, C. (2005). Fair Trade: The Story So Far. Fair Trade. In A. Nicholls \& C. Opal (Eds.), Market-Driven Ethical Consumption (pp. 16-32). London: SAGE Publications Ltd. doi: $10.4135 / 9781446211526$

O'Donovan, G., (2002). Environmental disclosures in the annual report. Accounting, Auditing \& Accountability Journal, 15 (3), pp. 344-371.

O'Dwyer, B., \& Unerman, J. (2016). Fostering rigour in accounting for social sustainability. Accounting, Organizations and Society, 49, 32-40. doi: 10.1016/j.aos.2015.11.003

O'Dwyer, B., \& Unerman, J. (2008). The paradox of greater NGO accountability: A case study of Amnesty Ireland. Accounting, Organizations and Society, 33(7), 801-824. doi: 10.1016/j.aos.2008.02.002

O'Sullivan, N., \& O'Dwyer, B. (2015). The structuration of issue-based fields: Social accountability, social movements and the Equator Principles issue-based field. Accounting, Organizations and Society, 43, 33-55. doi: 10.1016/j.aos.2015.03.008

Owen, D. (2008). Chronicles of wasted time?: A personal reflection on the current state of, and future prospects for, social and environmental accounting research. Accounting, Auditing \& Accountability Journal, 21(2), 240-267. doi:10.1108/09513570810854428

Patten, D.M.,(2019). Seeking legitimacy. Sustainability Accounting, Management and Policy Journal, In Press 
Patten, D. M. (1991). Exposure, legitimacy, and social disclosure. Journal of Accounting and Public Policy, 10(4), 297-308. doi: 10.1016/0278-4254(91)90003-3

Perez, L. F.-R., \& Robson, K. (1999). Ritual legitimation, de-coupling and the budgetary process: managing organizational hypocrisies in a multinational company. Management Accounting Research, 10(4), 383-407. doi: 10.1006/mare.1999.0114

Phillips, B. (2010, 18 September, 2010). Sainsbury's disputes Co-op Fairtrade claims The Grocer.

Preston, A. M., Cooper, D. J., \& Coombs, R. W. (1992). Fabricating budgets: A study of the production of management budgeting in the national health service. Accounting, Organizations and Society, 17(6), 561-593. doi: 10.1016/0361-3682(92)90014-J

Puxty, A. (1991), Social accountability and universal pragmatics, Advances in Public Interest Accounting, 4, pp. 35-45.

Puxty, A.G., (1986). Social accounting as immanent legitimation: a critique of a technicist ideology. Advances in public interest accounting, 1(6), pp. 95-111.

Qian, W., Burritt, R., \& Monroe, G. (2011). Environmental management accounting in local government: A case of waste management. Accounting, Auditing \& Accountability Journal, 24(1), 93-128. doi: 10.1108/09513571111098072

Rahaman, A. S., Everett, J., \& Neu, D. (2007). Accounting and the move to privatize water services in Africa. Accounting, Auditing \& Accountability Journal, 20(5), 637. doi: 10.1108/09513570710778992

Ramirez, C., Stringfellow, L., \& Maclean, M. (2015). Beyond segments in movement: a "small" agenda for research in the professions. Accounting, Auditing \& Accountability Journal, 28(8), 1341-1372. doi: 10.1108/AAAJ-01-2015-1946

Raynolds, L., \& Long, M. A. L. (2007). Fair/ Alternative Trade: historical and emperical dimensions. In L. T. Raynolds, D. L. Marray \& J. Wilkinson (Eds.), Fair trade: the challenges of transforming globalization (pp. 15-32). London [u.a.]: Routledge.

Raynolds, L. T. (2012). Fair Trade: Social regulation in global food markets. Journal of Rural Studies, 28(3), 276. doi: 10.1016/j.jrurstud.2012.03.004

Raynolds, L. T., \& Murray, A. D. L. (2007). Globalizations and its antimonies: negotiating a Fait Trade movement. In L. T. Raynolds, D. L. Murray \& J. Wilkinson (Eds.), Fair trade: the challenges of transforming globalization (pp. 3-14). New York: Routledge.

Renard, M.-C., \& Loconto, A. (2013). Competing Logics in the Further Standardization of Fair Trade: ISEAL and the Símbolo de Pequeños Productores. International Journal of Sociology of Agriculture \& Food, 20(1).

Robinson, P. K. (2009). Responsible retailing: regulating fair and ethical trade. Journal of international development, 21(7), 1015-1026. doi: 10.1002/jid.1635

Scott, S. V., \& Orlikowski, W. J. (2012). Reconfiguring relations of accountability: Materialization of social media in the travel sector. Accounting, Organizations and Society, 37(1), 26-40. doi: 10.1016/j.aos.2011.11.005

Semeen, H., Islam, M. A., \& Quayle, A. (2016). The accounting and accountability practices of Fairtrade International (FLO). Social and Environmental Accountability Journal, 36(3), 170187. doi: 10.1080/0969160X.2016.1246376

She, C., \& Michelon, G. (2019). Managing stakeholder perceptions: Organized hypocrisy in CSR disclosures on Facebook. Critical Perspectives on Accounting, 61, 54-76. doi: 10.1016/j.cpa.2018.09.004

Shorette, K. (2010-11). Fair Trade and the Double Movement: The Promise and Contradictions of Improving Labor Standards in the Global South via Market Mechanisms. Journal of Workplace Rights, 15(3-4), 461-481. doi: 10.2190/WR.15.3-4.0

Sikka, P., (2011). Accounting for human rights: The challenge of globalization and foreign investment agreements. Critical Perspectives on Accounting, 22(8), pp.811-827.

Sylla, N. S., \& Leye, D. C. m. (2014). The fair trade scandal: marketing poverty to benefit the rich (1 ed.). London: Pluto press.

The Irish News. (2006, 27 October 2006). Starbucks accused in trade row The Irish News, p. 26. 
Thomson, I., Dey, C., \& Russell, S. (2015). Activism, arenas and accounts in conflicts over tobacco control. Accounting, Auditing \& Accountability Journal, 28(5), 809-845. doi: 10.1108/AAAJ08-2013-1439.

Tinker, T., Lehman, C. and Neimark, M. (1991), Falling down the Hole in the Middle of the Road: Political Quietism in Corporate Social Reporting, Accounting, Auditing and Accountability Journal, 4 (2), 28-54.

Toubiana, M., \& Zietsma, C. (2017). The message is on the wall? Emotions, social media and the dynamics of institutional complexity. Academy of Management Journal, 60(3), 922-953.

Traidcraft. (2015). Traidcraft: Fighting poverty through trade. Retrieved from http://www.traidcraft.co.uk

Uddin, S., Siddiqui, J., \& Islam, M. A. (2016). Corporate Social Responsibility Disclosures, Traditionalism and Politics: A Story from a Traditional Setting. Journal of Business Ethics, 120. doi: 10.1007/s10551-016-3214-7

Ullrich, H. (2011). Civil Society and the World Fair Trade Organization: developing responsive accountability. In J. A. Scholte (Ed.), Building Global Democracy?: Civil Society and Accountable Global Governance (pp. 289-305): Cambridge University Press.

Valiente-Riedl, E. (2013). Is Fairtrade Fair? Retrieved from http://www.palgraveconnect.com.ezp01.library.qut.edu.au/pc/doifinder/10.1057/9781137284 518.0001.

Valkila, J. (2009). Fair Trade organic coffee production in Nicaragua: sustainable development or a poverty trap? Ecological Economics, 68(12), 3018-3025. doi: 10.1016/j.ecolecon.2009.07.002

Webb, J., Schirato, T., \& Danaher, G. (2002). Understanding Bourdieu. Crows Nest, N.S.W: Allen \& Unwin.

WFTO and FLO. (2009). A Charter of Fair Trade Principle. from http://www.fairtradeadvocacy.org/about-fair-trade/what-is-fair-trade/charter-of-fair-trade-principles

WFTO and FLO. (2018). The International Fair Trade Charter. from http://www.fairtradeadvocacy.org/about-fair-trade/what-is-fair-trade/charter-of-fair-trade-principles

Wheeler, K. (2012). The Practice of Fairtrade Support. Sociology, 46(1), 126-141. doi: $10.1177 / 0038038511416162$

Wong, R., \& Millington, A. (2014). Corporate social disclosures: a user perspective on assurance. Accounting, Auditing \& Accountability Journal, 27(5), 863-887. doi: 10.1108/AAAJ-062013-1389

Young, J. J. (2003). Constructing, persuading and silencing: the rhetoric of accounting standards. Accounting, Organizations and Society, 28(6), 621-638. doi: 10.1016/S0361-3682(02)000168. 